\title{
Late Aptian-Albian primitive Radiolitidae (bivalves, hippuritoidea) from Spain and SW France
}

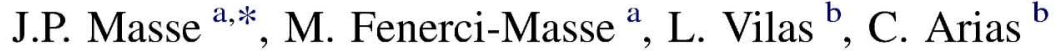 \\ ${ }^{a}$ Centre de sédimentologie-paléontologie, laboratoire associé au CNRS, Université de Provence, 13331 Marseille Cedex 03, France \\ ${ }^{\mathrm{b}}$ Departamento de Estratigrafia, Instituto de Geologia Economica (CSIC-UCM), Facultad de C.C. Geologicas, Universidad Complutense, \\ 28040 Madrid, Spain
}

\begin{abstract}
The late Aptian-Albian radiolitid taxa, Praeradiolites cantabricus (Douvillé) and Praeradiolites ibizanus Astre, from SW France and Spain, are transferred to Eoradiolites. Eoradiolites jumillensis nov. sp. is described from southern Spain, while the so-called "Sphaerulites cantabricus" sensu Toucas (1907) is moved to Praeradiolites and may be of Late Cretaceous age. The Eoradiolites cantabricus group of species is mainly Clansayesian-early Albian in age and possesses an advanced evolutionary status, mainly regarding shell size and cellular structure. Praeradiolites may have been derived from Eoradiolites jumillensis nov. sp. through paedomorphosis while Eoradiolites cantabricus may have been the source for Sphaerulites. Our study shows that the names Sphaerulites and Praeradiolites cannot be applied to pre-Cenomanian Radiolitidae and that Eoradiolites was the foremost genus in Late Aptian-Albian times in terms of species biodiversity. The Eoradiolites cantabricus group is restricted to the northwestern Mediterranean Tethyan margin.
\end{abstract}

Keywords: Rudist bivalves; Early Cretaceous; Taxonomy; Radiolitidae; Spain-SW France

\section{Introduction}

The late Aptian-Albian marked the onset of the radiation of the rudist family Radiolitidae, which followed the mid-Aptian crisis affecting shallow water carbonate platform biotas, including rudists (Masse, 1989; Masse and Gallo-Maresca, 1997). This family regarded as monophyletic (Skelton and Smith, 2000), is characterized by the following attributes (synapomorphies): (1) shell structure: the outer calcitic shell layer tends to exhibit a cellular microstructure, with various geometrical patterns and (2) myocardinal features: myophores of the left valve (LV) are represented by vertical plates that project down into the right valve (RV); teeth are nearly equal and also project deeply in sockets or gutters of the opposite valve.

\footnotetext{
* Corresponding author.

E-mail address: jean-pierre.masse@ up.univ-mrs.fr (J.P. Masse).
}

The so-called "cellular structure" has been attributed by earlier workers (Palmer, 1928; Böggild, 1930; Douvillé, 1935; Milovanovic, 1935; Masse and Philip, 1972; Strum and Perkins, 1975; Amico, 1977; Steuber, 1999) to the association of two distinct sets of laminae or plates: the funnel plates, here labelled plates, and the radial plates, "muri" or walls, orthogonal to the plates, here labelled walls.

In primitive radiolitids the orientation of the funnel plates tends to be at low angle with the shell axis and the intersection of these plates with the radial walls form rectangular hollow prisms. Fig. 1 shows how the orientation of a given section cut in a right valve may illustrate aspects of the major constructional elements of the outer shell layer, and the corresponding terminology.

Primitive Radiolitidae documented from Aquitaine (SW France), the Basco-Cantabrian region and the Balearic Islands (Ibiza) (Fig. 2) include several species which have been variously ascribed either to Radiolites, Sphaerulites and Praeradiolite. 


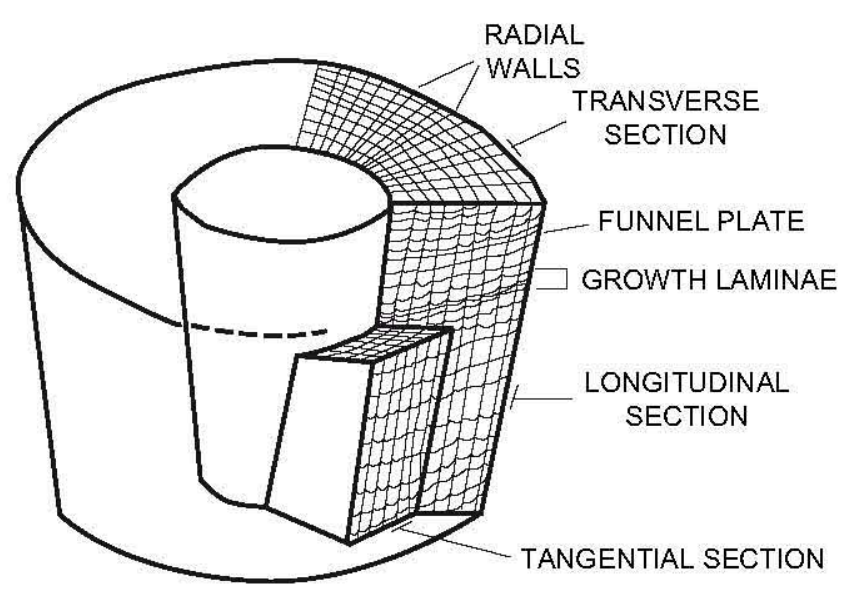

Fig. 1. Diagram showing how radial, transverse and tangential sections reveal the organisation of the cellular structure of the RV of the Radiolitidae (modified after Amico, 1977).

The objective of the present paper is to reappraise the generic and specific position of Praeradiolites cantabricus (Douvillé) (Douvillé, 1889, 1900, 1902), a form figured as Sphaerulites cantabricus (Douvillé) by Toucas (1907) and Praeradiolites ibizanus Astre (Astre, 1935). A new species of Eoradiolites from the vicinity of Jumilla (Southern Spain), formerly considered a representative of Praeradiolites (Masse et al., 1992, 1998a; Gallo-Maresca, 1993) is also described. Besides increasing taxonomic clarity this revision has a significant bearing concerning: (1) the evolutionary status of these forms in the context of the radiation of the Radiolitidae during the late Aptian-Albian, (2) their use as biostratigraphic tools, and (3)

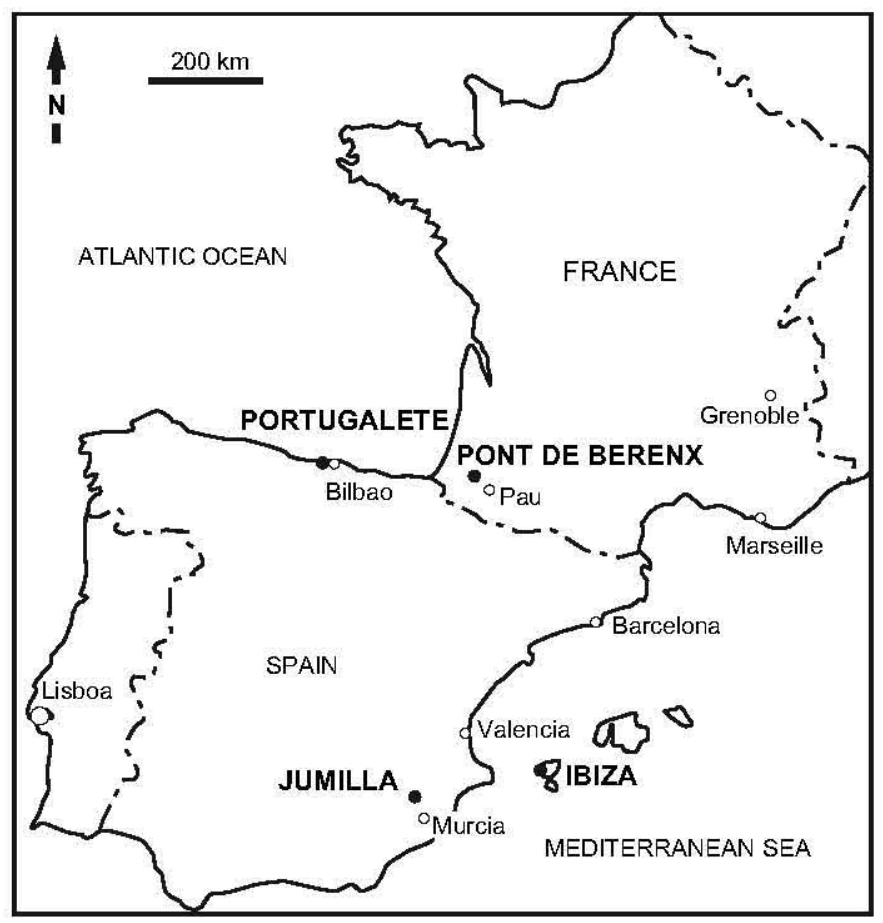

Fig. 2. Geographical distribution of Upper Aptian-Albian sites bearing Radiolitidae in SW Europe. biodiversity patterns and dynamics of the primitive forms of the family Radiolitidae, which evolved during a phase of recovery succeeding to the mid-Aptian extinction event.

\section{Systematic palaeontology}

In order to address the issue of taxonomic position of the foregoing forms, the diagnostic characters of the genera Radiolites, Sphaerulites, Praeradiolites and Eoradiolites to which the studied species have been previously ascribed need to be summarised. Genus definitions are essentially based on characters of the right valve. The following derive from Dechaseaux and Coogan in Dechaseaux et al. (1969), complemented by data from Amico (1977) concerning the shell cellular patterns, as well as personal observations.

Order: Hippuritoida Newell, 1965

Superfamily: Hippuritoidea Gray, 1848

Genus Radiolites Lamarck, 1801

Type species. Ostracites angeiodes de Lapeirouse, 1781

Diagnosis. Strong longitudinally undulated folds of growth laminae around the whole right valve, radial bands smooth zones flanked by regular folds. Shell structure cellular: polygonal to elongated rectangular.

Genus Sphaerulites Lamarck, 1815-22

Type species. Sphaerulites foliaceus Lamarck, 1815-22

Diagnosis. Foliated growth laminae, undulating, radial bands depressed flanked by folds and corresponding internally with two convex inward bulges. Shell structure coarsely rectangular, radially elongated.

Remark. Shell flattening is associated with an elongation of the ligament ridge and the inward migration of the myophores (usually observed flanking the inner shell layer in other genera).

Genus Praeradiolites Douvillé, 1902

Type species. Radiolites fleuriaui d'Orbigny, 1842

Diagnosis. Radial bands formed by undulated, convex upward, growth laminae, interband concave upward. Shell structure cellular, mostly rectangular, short, locally polygonal (radial bands).

Genus Eoradiolites Douvillé, 1909

Type species. Radiolites davidsoni Hill, 1893

Diagnosis. Growth laminae strongly oblique to shell axis, radial bands salient with flattened outer faces, cellular structure rectangular, short, compact laminae frequent. 
Discussion. Distinguishing Eoradiolites from Praeradiolites has been frequently somewhat problematical even for Douvillé himself. This is the case for Praeradiolites sinaiticus Douville (Douvillé, 1913a), which was subsequently transfered to Eoradiolites (Douvillé, 1926) because of the similarity of the radial bands with those of $E$. davidsoni. The same difficulty arose for Praeradiolites hedini Douvillé (Douvillé, 1916), transferred by Bobkova (1974) to Eoradiolites. Moreover, notwithstanding the analogy regarding the radial bands with E. davidsoni, the species gilgitensis (from Gilgit, Pakistan) was assigned to Praeradiolites (Douvillé, 1926). The challenge is actually to interpret transverse sections relatively to the geometry of the growth laminae observed on the ventral shell surface. The study of a collection of Praeradiolites including various Turonian/Coniacian species, e.g. Praeradiolites subtoucasi Toucas, and Eoradiolites, e.g. E. davidsoni, cut transversally provides a clue for distinguishing the two genera from shell growth patterns, as shown by Gallo-Maresca and Masse (1993) (Fig. 3). In Eoradiolites postero-ventral bands are marked by convex outward growth laminae, i.e. parallel to the shell surface. In Praeradiolites, in contrast, the convex upward folding of growth laminae of the radial bands corresponds transversally with concave outward growth laminae, the interband being convex outward.
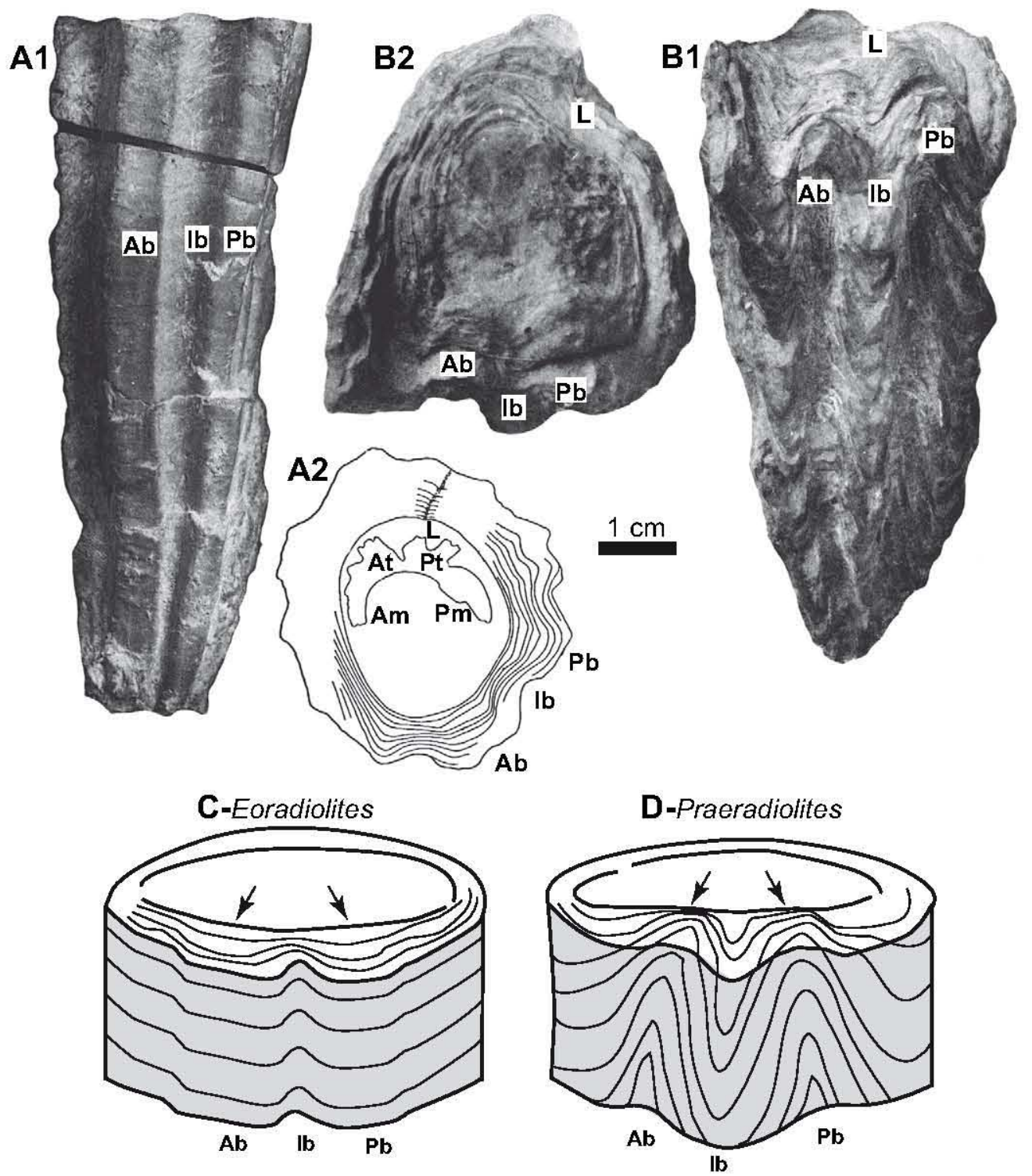

Fig. 3. Morphological and structural attributes of Eoradiolites and Praeradiolites. A1, ventral view of Eoradiolites davidsoni (Hill) showing the flattened and salient radial bands ( $\mathrm{Ab}$, anterior band; $\mathrm{Ib}$, interband; $\mathrm{Pb}$, posterior band) from (Douvillé, 1910, plate 1, figure 1). A2, adapical transverse section of the same specimen showing the shape and internal structure of the radial bands (from Douvillé, 1910, figure 9, p. 14). B1, ventral view of Praeradiolites subtoucasi Toucas, showing the convex upward bands and concave upward interband. B2, external view of LV of the same specimen showing the salient interband and depressed bands (Toucas, 1907, plate 13, figure 8 and 8a). 3D models illustrating the internal structure of radial bands in Eoradiolites (C) and Praeradiolites (D). Notice that in Praeradiolites the convex upward folds (i.e. "sinuses") from the outer shell surface correspond in transverse section with depressed concave outward structures, whereas in Eoradiolites the structure is conform to the outer shell surface. Reproduction of Douvillé and Toucas original figures by courtesy of Société géologique de France. 
Eoradiolites cantabricus (Douvillé)

Figs. $4-8$

1889 Radiolites cantabricus Douvillé, p. 649-652, figs. $17,18$.

1902 Praeradiolites cantabricus Douvillé; Douvillé, p. 469.

non 1907 Sphaerulites cantabricus Douvillé; Toucas, p. 11, fig. 3.

non 1954 Sphaerulites cantabricus (Douvillé) Toucas; Astre, p. 93-94.

\section{Description}

Douville data. The original description of Radiolites cantabricus by Douvillé mainly referred to comparisons with some representatives of Sphaerulites and Radiolites: Sphaerulites foliaceus Lamarck, Radiolites triangularis d'Orbigny and $R$. fleuriaui d'Orbigny. The latter forms were later transferred to Eoradiolites or Praeradiolites (see Douvillé, 1902, 1909). Likewise, when erecting the genus Praeradiolites (type species P. fleuriaui) to which Douvillé (1902) transferred his Cantabrian species, little was added to the original description so the specific characters of this taxon were poorly documented. In his original description of R. cantabricus, Douvillé (1889, p. 652 ) noticed that the radial bands "are distinguished by inflexions of growth plates" (authors' translation). Later on he was stressing that the bands are less salient than those of Eoradiolites davidsoni, the posterior one being also less accentuated than that of Praeradiolites fleuriaui. The original illustration (Douvillé, 1889, figure 18), a commissural view of the right valve, indicates the position of $\mathrm{Ab}$ (anterior band) and $\mathrm{Pb}$ (posterior band) fitting with inward inflexions of the growth laminae, whereas it is not clear from the drawing if these inflexions correspond to salient or depressed areas of the outer shell.

Data derived from the revision of the type material. Owing to the above shortcomings in the description of the radial bands (with a significant impact on generic position), the type material was re-examined in order to establish whether or not the species could be retained in the genus Praeradiolites. The Douvillé specimens are housed in the Centre commun des collections de géologie (Université Claude Bernard Lyon 1). In his original work Douvillé (1889) did not formally designate a holotype but his description mainly relates to the isolated well-preserved right valve from Portugalete (Douvillé, 1889, fig. 18) rather than the orientated sections cut into the bivalve specimen from Pont de Berenx (Douvillé, 1889, fig. 17). This opinion is corroborated by the species name referring to Cantabria, where Portugalete is located. Accordingly the former specimen is designated as the name-bearing lectotype of the species, illustrated herein as Fig. 4a, b. This choice contradicts Astre's (1954) identification of Pont de Berenx as the type locality because the corresponding specimen was illustrated first in Douvillé's original paper. Actually this longitudinal axial section, somewhat meaningful regarding the attributes of the Eoradiolites-Praeradiolites group, cannot be considered significant at generic level because the ventral side, bearing the diagnostic radial bands was not illustrated, warranting its rejection as a valuable type figure. Nevertheless the material from Pont de Berenx will deserve a careful discussion.

Revision of the lectotype (R766) (Portugalete). The valve is conical with an elliptical transverse outline, the anteroposterior commissural diameter $(\mathrm{dAP}=10 \mathrm{~cm})$ being smaller than the dorso-ventral one $(\mathrm{dDV}=12.5 \mathrm{~cm})$. The height/ diameter ratio fluctuates from 0.8 (when using $\mathrm{dDV}$ ) to 1 (when using dAP). The distance between the shell edge to the inner margin of the outer shell layer (that is where the junction with the lost aragonitic inner shell was situated) fluctuates from $2 \mathrm{~cm}$ (anterior ridge) to $3.5 \mathrm{~cm}$ (anterior and dorsal sides). The corresponding "growth surface" slopes significantly inward (Fig. 4A) in correspondence to the overall orientation of the growth laminae. The shape of the inner margin is elliptical but, in contrast with the commissure, $\mathrm{dDV}(6.7 \mathrm{~cm})$ is smaller than dAP $(7.8 \mathrm{~cm}$ ) (Fig. 4A). Accordingly the shell thickness is higher on the dorso-ventral diameter than on the antero-posterior one. Growth laminae form the external ornamentation. The $\mathrm{Ab}$ is flat (Figs. $4 \mathrm{~A}, 5 \mathrm{~A}-\mathrm{C}$ ), moderately salient and relatively wide $(2.7 \mathrm{~cm})$ whereas the $\mathrm{Pb}$ is more convex outward and slightly narrower $(2.2 \mathrm{~cm})$, the depressed $\mathrm{Ib}$ being smaller $(1.2 \mathrm{~cm})$. The wavy inflexions of the bands on the outer shell surface merely reflect erosional features rather than structural patterns, the commissure being nearly flat on the corresponding ventral area.

Ontogenetic variations include: (1) orientation of growth laminae: in the juvenile growth laminae are at a high angle to the shell axis, i.e. the overall shape is flattened (Fig. 5A-E), growth laminae angle to the shell axis tends to reduce in the adult stage, i.e. the shape becomes conical; these modifications are coupled with a reduction in the lamellar character of the outer shell surface; (2) radial bands are inconspicuous in the juvenile and develop during the adult stage (Fig. 5A-B).

Internal characters are relatively well preserved, including (Fig. 4A-B): pediculate ligament ridge, the truncated face of which is oriented posteriorly; "tooth-sockets" are represented by gutters with longitudinal sliding-grooves (Fig. 4B) $2.5 \mathrm{~cm}$ long and $0.8 \mathrm{~cm}$ wide for the posterior, and $3.5 \mathrm{~cm}$ long for the anterior (because the gutter margins are partly broken the width is difficult to estimate); the deeper part (apical area) of the cardinal apparatus is filled with sediment and expected to present sockets s.s., whereas the central tooth is not preserved; muscle scars flanking the cardinal gutters, the posterior being smaller and more concave that the anterior, with a triangular outline (Fig. 4A).

Description of the specimen from Pont de Berenx (R472). This specimen was illustrated by a longitudinal partial section (Douvillé, 1889, p.650, fig. 17) in the original description. Actually besides the view shown by Douville, the specimen (Fig. 6A) displays a transverse section cutting the myocardinal elements (Fig. 6B) and an oblique transverse section cut close to the apex illustrating the ventral side (Fig. $6 \mathrm{C}$ ). The overall dimensions, height $(6.5 \mathrm{~cm})$ and $\mathrm{dAP}(6.5 \mathrm{~cm})$ are smaller than 

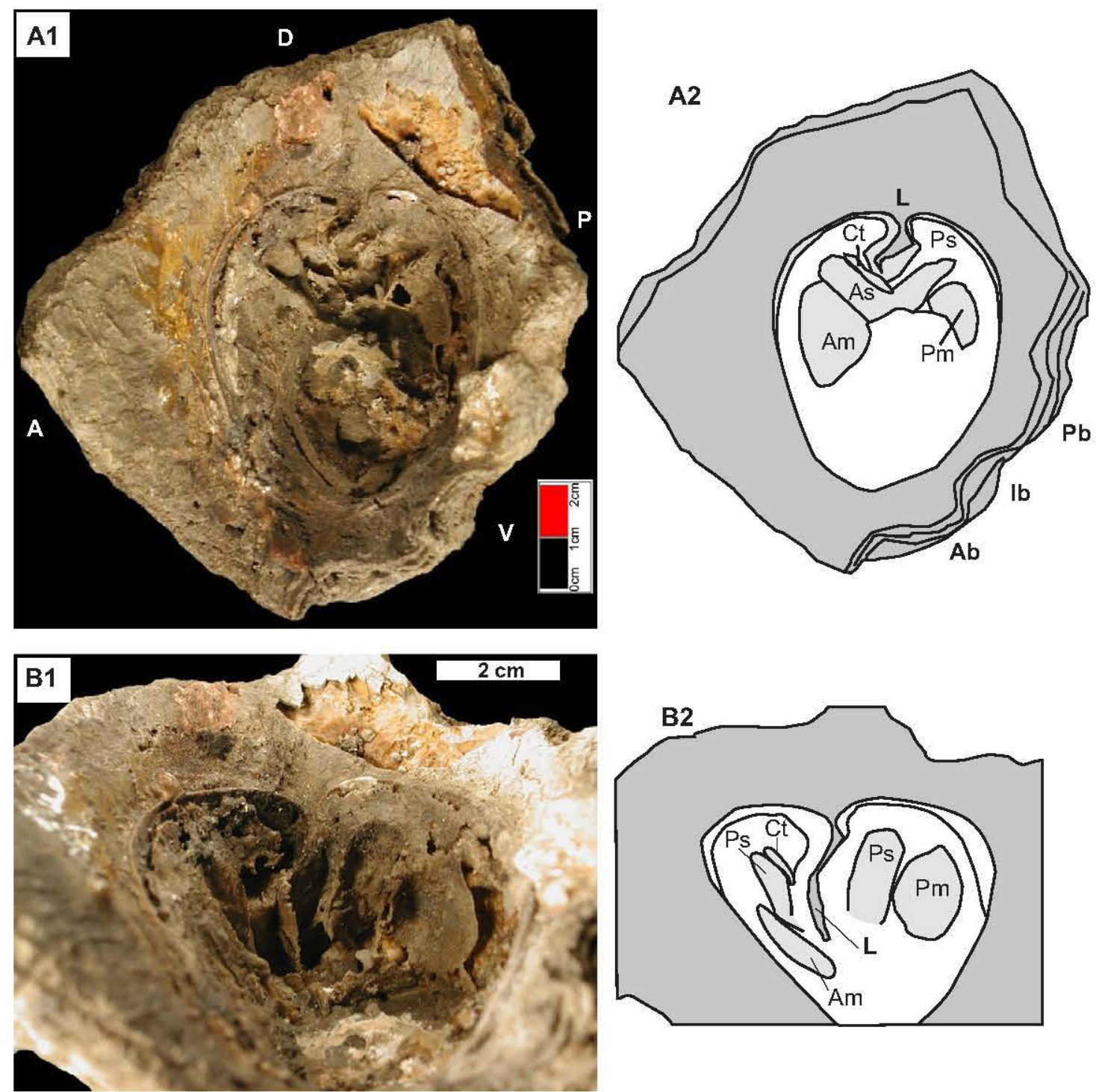

Fig. 4. Eoradiolites cantabricus (Douvillé). Lectotype, Portugalete, RV. A1-A2, adapical view showing the subquadrangular shell outline, the elliptical inner shell margin, the interpretation of the myocardinal elements, and the position of the radial bands. B1-B2, oblique view of the myocardinal apparatus and its interpretation. Symbols used for palaeontological description. LV, left valve; RV, right valve; D, dorsal; V, ventral; A, anterior; P, posterior; Pm, posterior myophore; Pmp, posterior myophoral plate; Am, anterior myophore; Amp, anterior myophoral plate; Ps, posterior socket or gutter; As, anterior socket or gutter; Ct, central tooth; Pt, posterior tooth, At, anterior tooth; $\mathrm{L}$, ligament ridge; $\mathrm{Ab}$, anterior band; $\mathrm{Pb}$, posterior band; $\mathrm{Ib}$, interband; Ac, accessory cavity; tbl, tabulae. For each figure the body cavity and other anatomical cavities, e.g. tooth sockets, in white; inner originally aragonitic shell layer in pale grey; outer calcitic shell layer dark grey.

those of the type specimen from Portugalete. The growth laminae orientation of Fig. $6 \mathrm{~A}$ and the position of the section of Fig. 6C show that the specimen represents a small portion of an individual with dimensions closely comparable to those of the type specimen, as illustrated on the reconstruction in Fig. 7. The cardinal organisation conforms to that of the type specimen, e.g. cardinal gutters with posterior slidinggrooves. The transverse (half section) cut near the commissure shows the bulbous termination of the ligament ridge of the left valve, whereas in the basal oblique transverse section the ligamental area was broken. The strongly oblique growth laminae and the organisation of the shell margin are also comparable to those of the Cantabrian specimen. Unfortunately the radial bands are not fully preserved on the oblique transverse basal sections but are indicated by the flattening of the inner shell margin. Interpreting specimen R472 as a representative of "Radiolites" cantabricus identifies it as a paralectotype, and bears significant additional information on this species, regarding the following aspects. The left valve is nearly flat, slightly depressed and bears no cellular structure. The edge (commissural margin) is marked by a thickening of the calcitic outer layer fitting with the inner, sloping inward portion of the growth surface of the right valve. The myophoral plates are slightly diverging downward (Fig. 6A), a feature which reflects the rapid shell diameter enlargement during vertical growth, whereas in cylindrical radiolitids the myophoral plates are maintained nearly parallel to each other during shell growth. The basic geometry of the cellular structure is 

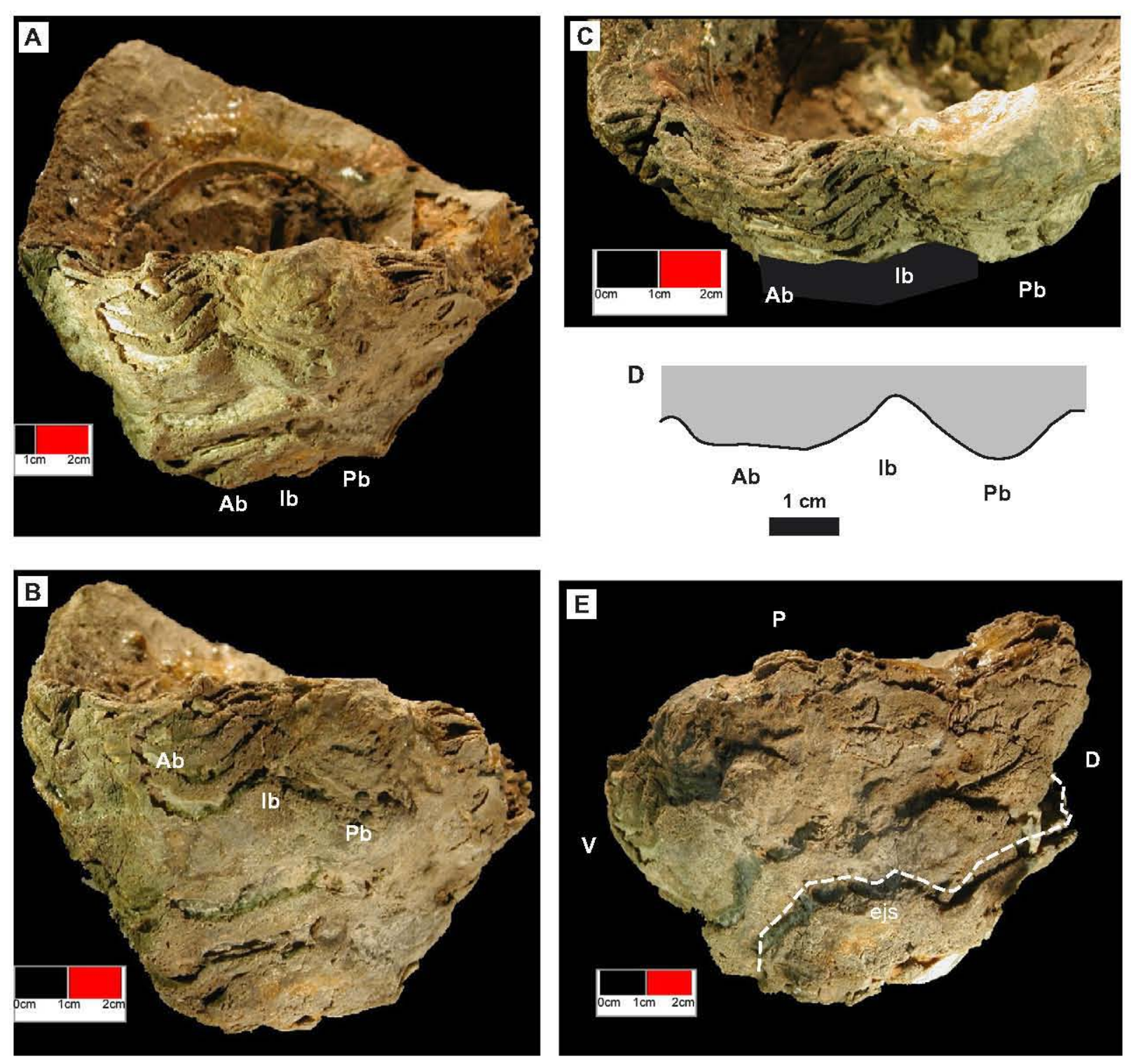

Fig. 5. Eoradiolites cantabricus (Douvillé). Lectotype, Portugalete, RV. A, B, ventral view showing the radial bands. a, adult stage with well developed radial bands; see in (C) a close-up view and a topographic sketch in (D). B, juvenile stage with inconspicuous radial bands. e, postero-dorsal view showing the flattened shell morphology of the early juvenile stage (ejs) reminiscent of Sphaerulites.

rectangular, transverse walls being thicker than funnel plates (Fig. 8A). The organisation of the outer shell microstructure for both longitudinal (Fig. 8B) and transverse (Fig. 8A) sections is marked by the alternation of thin compact and thick cellular layers. In transverse section, growth rhythms identified by successive sets of a compact + cellular layer may reflect an annual banding (Amico, 1977; Regidor-Higuera et al., 2002). Shell layers are locally interbedded with micritic sediment layers (Fig. 8B) indicative of temporary outward divergence of growth plates (sets of growth laminae, usually visible at the outer shell surface). The intercalation of compact laminae within the overall cellular structure represents the periodic integration of the cortical layer into the shell wall. This particular mode of relationship between the compact cortical layer and the inner cellular shell portions is called here embodied (Fig. 6A).
Concluding remark. The organisation of the radial bands conforms to those of Eoradiolites, so Praeradiolites is therefore inadequate for the former "Radiolites" cantabricus Douvillé, 1889. The quadrangular cellular shell structure also fits with that of Eoradiolites.

Revised diagnosis. Relatively large conical asymmetric Eoradiolites with a rounded elliptical transverse outline. Radial bands mostly develop during adult stage, the anterior wide and flat the posterior rounded and salient, interband a depressed gutter. Ventral carina moderately acute. Juvenile stage shell strongly lamellar becoming smooth at adult stage. Left valve flat with thickened calcitic edge fitting with the inner shell margin of the right valve. Tooth "sockets" corresponding to grooved gutters, ligament ridge pediculate. Anterior myophoral scar longer than the posterior. Quadrangular microstructure present in the entire calcitic 


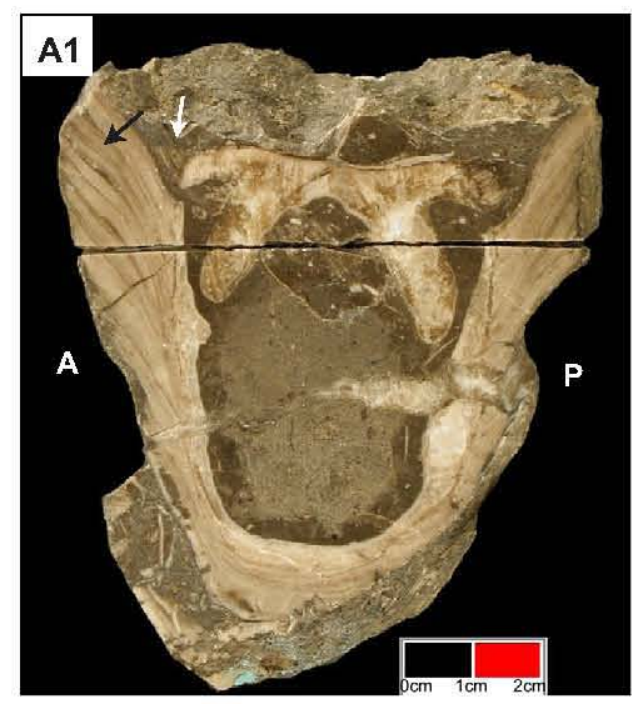

A2
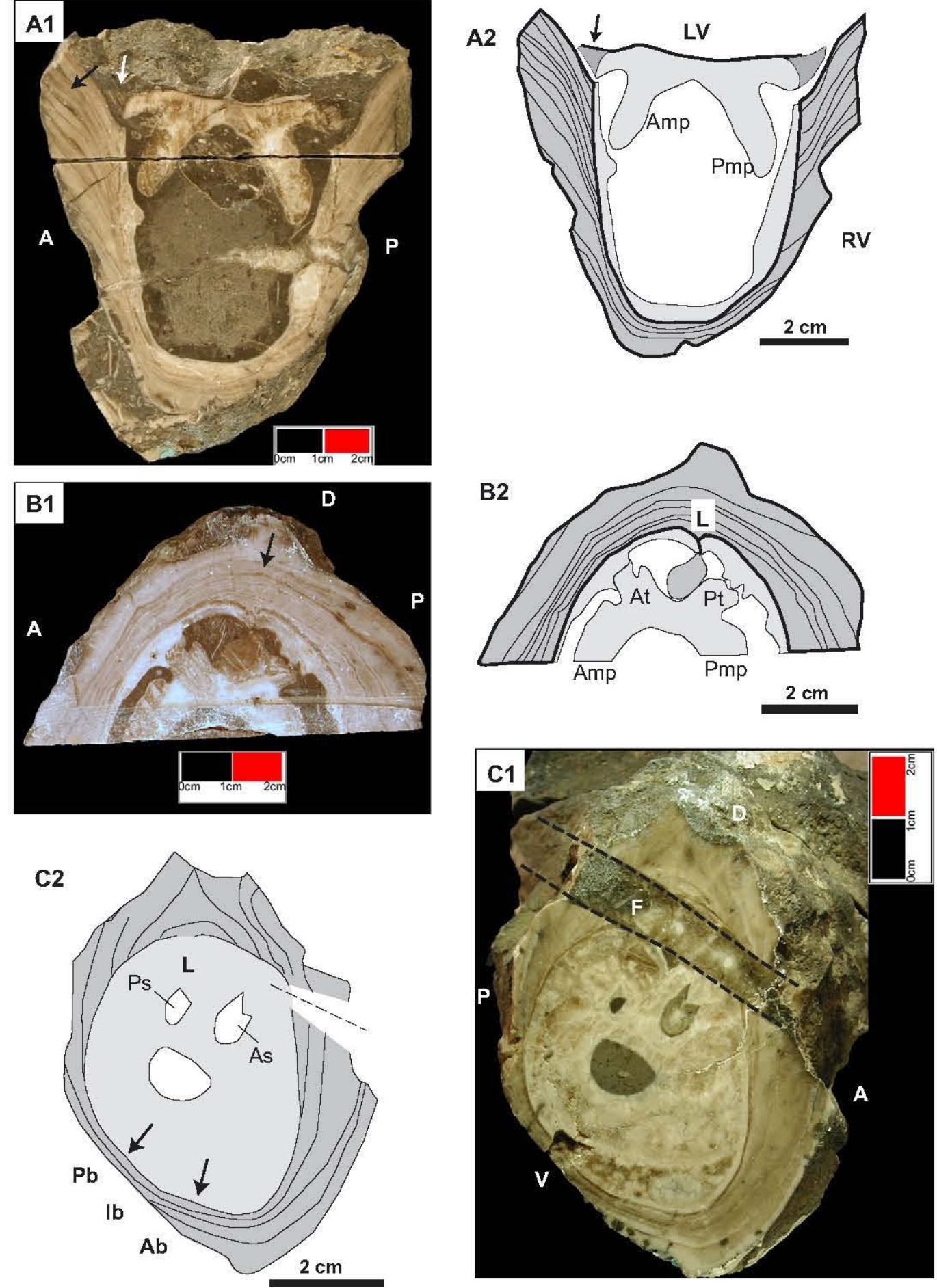

Fig. 6. Eoradiolites cantabricus (Douvillé). Paralectotype, Pont de Berenx, bivalve specimen. A1-A2, longitudinal section showing the shell growth laminae, the flat LV and the divergent myophoral plates (= figure 17 in Douvillé, 1889). Growth banding is mainly due to the periodical integration of the cortical layer in the cellular structure (embodied architecture). Notice on LV (arrow) the thickening of the calcitic outer shell layer, with a triangular longitudinal outline. B1-B2, RV, partial transverse adapical section showing the myocardinal elements and the bulbous end of the ligament ridge (from the LV). C1-C2, RV, oblique abapical transverse section close to the apex showing poorly defined radial bands; body cavity is reduced by early precipitation of aragonite filling the shell interior. Arrows point to flattened areas of the inner shell margin facing the radial bands. For Figure (A1) and (B1) arrows point to areas illustrated on Fig. 8 (microstructural aspects).

outer shell layer, interrupted periodically by compact laminae (cortical layer), the resulting shell architecture being embodied.

Comparison with other Eoradiolites species. Moving Praeradiolites cantabricus to the genus Eoradiolites necessitates comparison of this form with other described Eoradiolites species, essentially those of the Albian-Cenomanian. Table 1 provides morphometric attributes, mainly height (h) and [average $=(\mathrm{dAP}+\mathrm{dDV}) / 2$ ] diameter $(\mathrm{d})$ and the corresponding ratio $(\mathrm{h} / \mathrm{d})$ of 24 species from this interval. These data obtained 


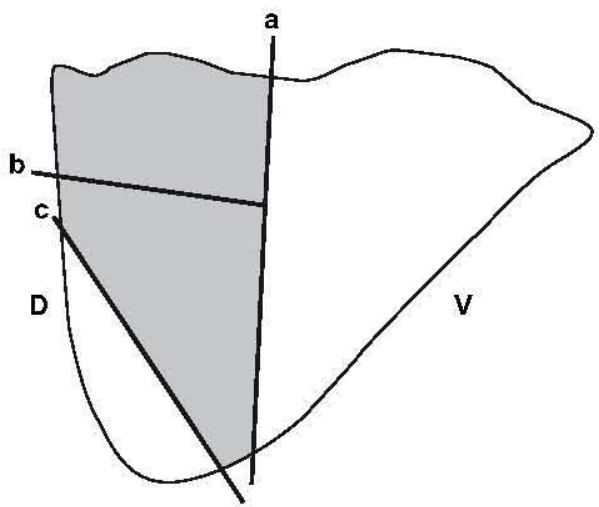

Fig. 7. Eoradiolites cantabricus (Douvillé). Paralectotype, Pont de Berenx (R 472). Geometrical sketch to show the position of the slab R472. A, longitudinal section; $\mathrm{B}$, transverse section; $\mathrm{C}$, oblique transverse section.

from the authors' descriptions or measured on the original figures derive from: Astre (1931), Bobkova (1974), Caffau and Plenicar (1991), Douvillé (1913b, 1916, 1926), Gallo-Maresca (1993), Parona (1909, 1921), Pejovic (1974), Sliskovic (1982), Tavani (1948), Toucas (1907) and specimens from the collection de paléontologie de l'Université de Provence, Marseille. Morphometric properties of the species described so far document various kinds of conical habits, from high conical ( $h /$ $\mathrm{d}>2$ ), to moderate $(1.2 \leq \mathrm{h} / \mathrm{d} \leq 2)$ and low conical ( $\mathrm{h} /$ $\mathrm{d}<1.2$ ). Eoradiolites cantabricus is typified by its low conical shape $(\mathrm{h} / \mathrm{d}=0.9)$ and its large size $(\mathrm{d}=10.6 \mathrm{~cm})$. Additional comments, especially regarding similarities and dissimilarities with E. ibizanus (Astre) and E. jumillensis nov.sp., all belonging to the $E$. cantabricus group, are given below. The average commissural diameter (d) fluctuates between 2 and $10.6 \mathrm{~cm}$ and the height ranges from $4 \mathrm{~cm}$ to $12 \mathrm{~cm}$ (Fig. 9).

Stratigraphical position. From the literature compiled by Bataller-Calatayud (1947) and Astre (1954) E. cantabricus appears to the most abundant radiolitid from the Uppermost
Aptian and Lower Albian in Spain and the Aquitano-Pyrenean region from SW France. Our observations in these regions (Masse, 1996; Masse and Gallo-Maresca, 1997; Masse et al., 1998a) show that E. cantabricus is rare. Portugalete is presently a city with a wide spatial extent and the location of de Verneuil et al. (1860), subsequently used by Douvillé (1889) and Toucas (1907) for their descriptions, is not precisely known. Moreover, rudists are not associated with shallow water sediments there but with allodapic deposits in which they occur sparsely. The corresponding age is early Albian, in agreement with Douvillé' s view (Fernandez-Mendiola, Basco-Cantabrian University of Bilbao, pers. comm.). Rudist-bearing carbonates from Pont de Berenx belong to the Arudy limestones, presently ascribed to the Clansayesian (N'da Loukou, 1984; Masse, 1996). "Radiolites" cantabricus has been reported from Portugal (but not illustrated) in beds with Orbitolina durandelgai Schroeder, ascribed to the Vraconian (uppermost Albian) (Rey et al., 1977). The stratigraphical range of Eoradiolites cantabricus is from the Clansayesian to the Albian (up to Upper Albian?).

\section{Eoradiolites ibizanus (Astre)}

Figs. 10-11

1935 Praeradiolites ibizanus, Astre, p. 89-92, figs. 1-4

1947 Praeradiolites ibizanus Astre, Bataller Calatayud, p.7779

1993 Praeradiolites ibizanus, Astre, Gallo-Maresca, p.79-80, fig. 20

In his original description Astre (1935) focused on the following features of the right valve: (1) conical foliated, lacking folds and relatively thick, compressed antero-posteriorly, with postero-ventral shell expansions, (2) "siphonal" bands i.e. $\mathrm{Pb}$ and $\mathrm{Ab}$ depressed, $\mathrm{Pb}$ narrower than $\mathrm{Ab}$, interband with a subrectangular salient outline, (3) ligamental dorsal area marked by a strong inward folding of growth laminae,
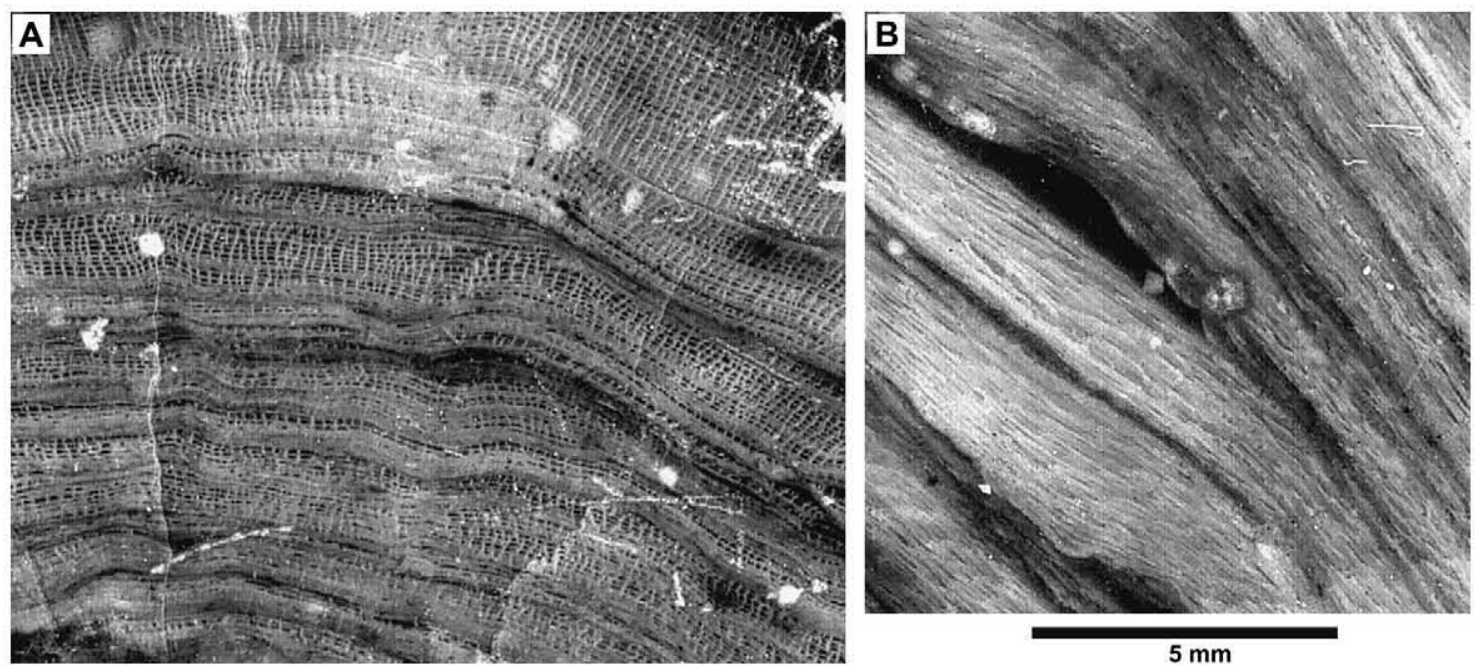

Fig. 8. Eoradiolites cantabricus (Douvillé). Paralectotype, Pont de Berenx. Shell microstructure. A, transverse section (dorsal side) showing the quadrangular cellular network, notice alternate cellular and compact laminae (cortical layer), also expressed on the longitudinal section (B) likely to reflect annual growth banding. 
Table 1

Morphometry of late Aptian - Cenomanian Eoradiolites species (d-diameter; h-height). Measurements based on holotypes

\begin{tabular}{lllll}
\hline & & $\mathrm{dm}(\mathrm{cm})$ & $\mathrm{h}(\mathrm{cm})$ & $\mathrm{h} / \mathrm{dm}$ \\
\hline 1 & Eoradiolites? acutilamellosus & 3 & 8 & 2.7 \\
& Caffau \& Plenicar & & & \\
2 & Eoradiolites adriaticus Caffau \& Plenicar & 2.3 & 8 & 3.5 \\
3 & Eoradiolites afghanicus Bobkova & 4 & 9 & 2.3 \\
4 & Eoradiolites cantabricus (Douvillé) & 10.6 & 10 & 0.9 \\
5 & Eoradiolites costicillatus Tavani & 3 & 5.1 & 1.7 \\
6 & Eoradiolites davidsoni (Hill) & 4.2 & 9.2 & 2.2 \\
7 & Eoradiolites durdurensis Tavani & 3.7 & 6.3 & 1.7 \\
8 & Eoradiolites franchii Parona & 2.5 & 6 & 2.4 \\
9 & Eoradiolites gradatus Bobkova & 6 & 6 & 1.0 \\
10 & Eoradiolites hedini (Douvillé) & 6 & 8.5 & 1.4 \\
11 & Eoradiolites ibizanus (Astre) & 6.2 & 8.3 & 1.3 \\
12 & Eoradiolites jumillensisnov. sp. & 7.5 & 8.4 & 1.1 \\
13 & Eoradiolites kalugini Bobkova & 6 & 12 & 2.0 \\
14 & Eoradiolites katzeri Sliskovic & 3 & 5 & 1.7 \\
15 & Eoradiolites kelifensis Bobkova & 5.5 & 5.8 & 1.1 \\
16 & Eoradiolites kugitangensis Bobkova & 5.1 & 5.3 & 1.0 \\
17 & Eoradiolites liratus (Conrad) & 3.1 & 7.5 & 2.4 \\
18 & Eoradiolites metohiensis Pejovic & 3 & $\times$ & $\times$ \\
19 & Eoradiolites murgensis Torre & 3.8 & 6 & 1.6 \\
20 & Eoradiolites plicatus (Conrad) & 2.5 & 6 & 2.4 \\
21 & Eoradiolites rousseli Toucas & 3.5 & 4 & 1.1 \\
22 & Eoradiolites triangularis (d'Orbigny) & 3 & 5.5 & 1.8 \\
23 & Eoradiolites zizensis Astre & 6 & 9 & 1.5 \\
24 & Eoradiolites zucchii Caffau \& Plenicar & 2 & 5.5 & 2.8 \\
\hline & & & &
\end{tabular}

(4) myocardinal apparatus parallel to shell edge, teeth with a rounded transverse outline, posterior myophoral plate rather distinct from the adjacent tooth, (5) upward folded growth laminae corresponding with depressed zones, i.e. sinuses. Left valve relatively thick, central zone more salient than outer margin, concentric rough ornamentation. The organisation of the radial bands (i.e. sinus $\mathrm{E}$ and $\mathrm{S}$ sensu Astre) was considered diagnostic of the genus Praeradiolites.

Revision of the type material. A bivalve specimen cut transversally ( $1 \mathrm{~cm}$ below the commissure) (UPS-GA 108) and housed

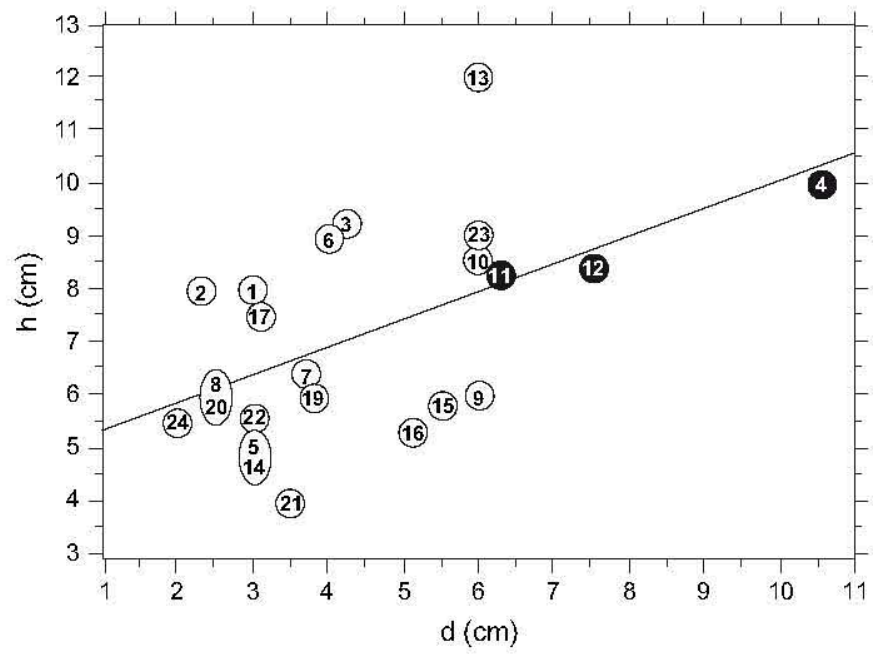

Fig. 9. Graph of the regression analysis of 23 Eoradiolites species concerning morphometric aspects. The Eoradiolites cantabricus group including $E$. cantabricus (4), E. ibizanus (11) and E. jumillensis nov. sp. (12) is in black. in the collections de Paléontologie, Université Paul Sabatier, Toulouse, leads us to discuss Astre's interpretation, mainly the location of the radial bands, their organisation and their taxonomic significance regarding the placement of the species in Praeradiolites. We locate the radial bands on the thickened portion of the postero-ventral side (Fig. 10), rather than on the posterior depressions indicated by Astre, and labelled $\mathrm{E}$ and $\mathrm{S}$ by him (Astre, 1935, p. 90, figures 2-4). The $\mathrm{Ab}$ is wide $(1.4 \mathrm{~cm})$ slightly depressed in the middle, the $\mathrm{Ib}$, narrower $(0.9 \mathrm{~cm})$ and weakly depressed, the $\mathrm{Pb}$ being wider $(1.3 \mathrm{~cm})$ and weakly convex outward. Bands are facing slightly convex inward inflexions of the inner shell margin, and the interband is associated with a flattening of this margin (Fig. 10). The bands correspond to upward shell inflexions of the commissural margin of the left valve (Fig. 11B). As shown on Fig. 11 the right valve gives no evidence for upward folded growth plates corresponding to the depressed shell margin and identified as sinuses according to Astre. Moreover the internal structure of the

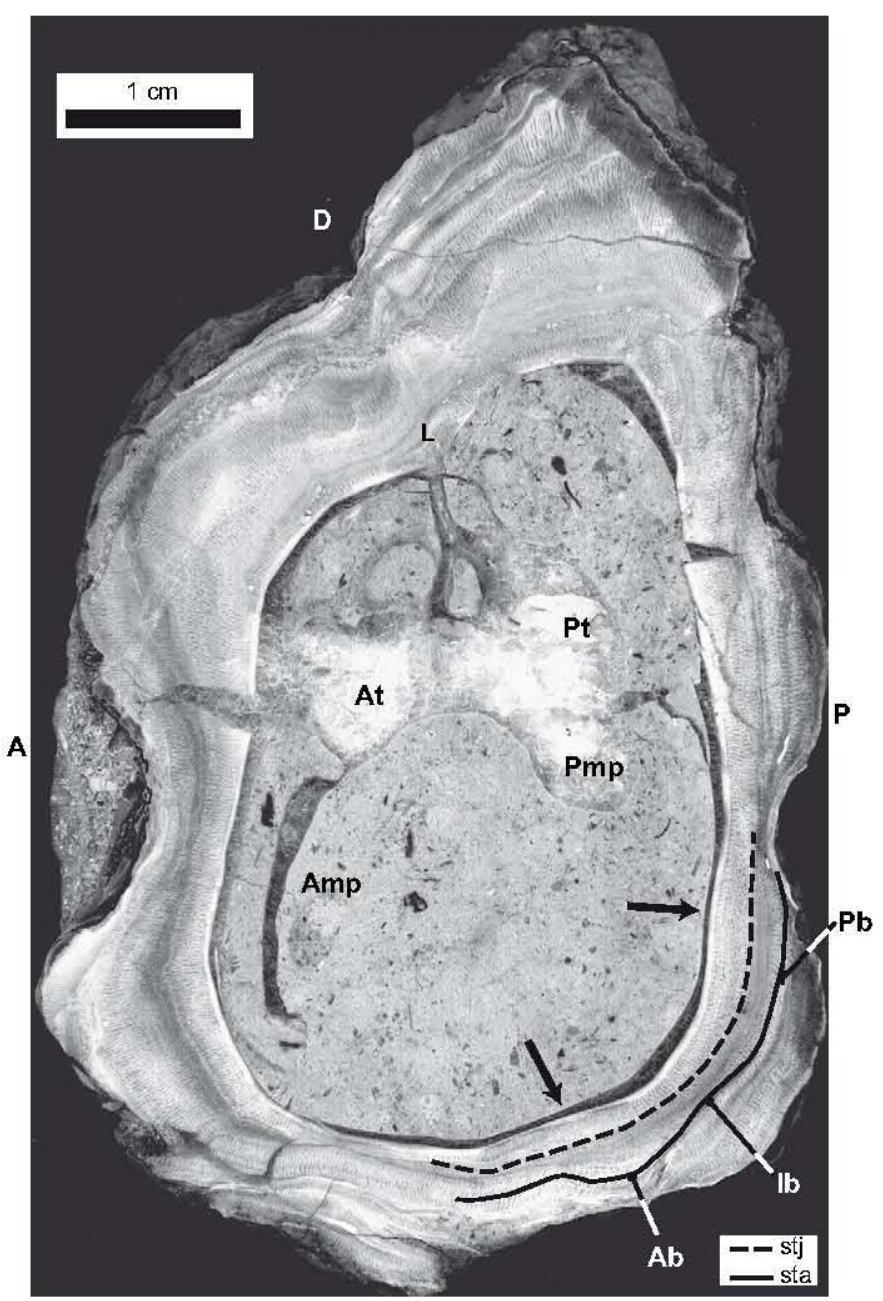

Fig. 10. Eoradiolites ibizanus (Astre). Holotype, Ibiza. RV, adapical transverse section showing the shell outline and the myocardinal elements. Notice the bulbous end of the ligament ridge of the LV, the asymmetry of the myophoral plates and the location of the radial bands. Arrows point to the flattened slightly convex inward areas of the inner shell margin facing the radial bands. Juvenile (stj) and adult (sta) growth stages of the bands. 


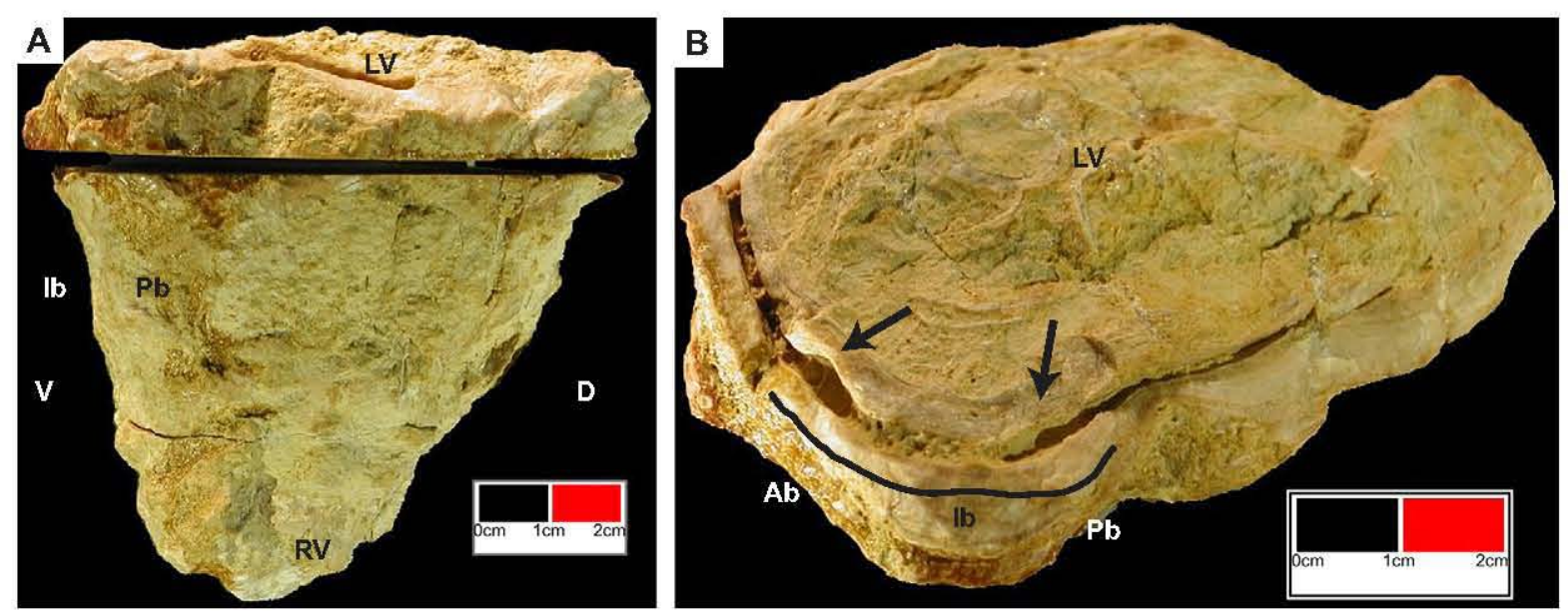

Fig. 11. Eoradiolites ibizanus (Astre). Holotype, Ibiza. a, posterior view showing the conical shape of the RV. b, oblique view of the LV illustrating (arrows) upward shell inflexions corresponding with the radial bands.

so-called $\mathrm{Ab}$ and $\mathrm{Pb}$ zones do not show the concave outward pattern that typifies Praeradiolites. Actually the location and organisation of radial bands are diagnostic of Eoradiolites, to which "Praeradiolites" ibizanus must be ascribed.

Our study confirms most of the characters reported by Astre, including the organisation of the dorsal zone and the postero-ventral shell expansions. As noted by Astre the antero-posterior shell compression is also a characteristic feature of the shell morphology. The triangular cracks present in the inner part of the calcitic shell layer are genetically related to the mechanical compression of the shell. The anteroposterior deformation due to this process represents only a few percent of the original diameter and cannot account for a significant modification of the original shape. Nevertheless the type material deserves additional comments addressing the shell outline, growth patterns, myocardinal organisation, the cellular structure of the outer shell layer of the right valve, and the shape of the left valve.

Moving the radial bands ventrally led to the need to reinterpret the two posterior depressions considered by Astre as the radial bands, consequently these features appear as a possible morphological attribute of Eoradiolites ibizanus. The wide depression located on the anterior side of the shell may also be a typical feature. Growth laminae associated with the bands parallel the inner shell margin (early growth stage) then become more convex outward (advanced growth stage) (Fig. 10). These ontogenetic variations show that radial bands are poorly differentiated during the early growth stage.

As noticed by Gallo-Maresca (1993), the interpretation of the myocardinal attributes given by Astre in his figure 3, concerning the central tooth of the right valve, is not correct, as the so-called $\mathrm{N}$ represents the bulbous end of the ligament ridge of the left valve. A striking feature is the asymmetry of the myophoral plates, the anterior being thin and extending to the antero-ventral articulation of the right valve whereas the posterior is short and rounded (Fig. 10). The outer shell layer is entirely cellular with a dominant quadrangular pattern. The cellular habit differs in relation to the different portions of the shell (Fig. 10). The dorsal side is characterized by a radial wavy pattern, locally amoeboid. This organisation relates to the orientation of growth plates, which tend to be perpendicular to the shell axis and/or deflected (bent) outward. This pattern extends to the antero-ventral articulation. In contrast, on the ventral and posterior sides the quadrangular pattern predominates in correspondence to more steeply inclined growth laminae. Amoeboid structures are developed in the radial bands, especially the posterior. Cell walls tend to be continuous from one row to another whereas their orientation is mostly wavy. This means that the radial walls of successive growth laminae are vertically superimposed. Fig. 10 shows that the integration of the cortical layer into the shell architecture appears limited, with the exception of the dorsal side.

Finally, whereas Astre was describing a left valve with a salient central zone, the type material shows an encrustation of this area by tubular, juvenile, radiolitids (Fig. 11) precluding clear observation of its shape. This valve apparently lacks a cellular structure.

Diagnosis. Relatively large, conical, moderately asymmetrical Eoradiolites with a subrectangular transverse outline due to an antero-posterior compression. Dorsal infolding of growth laminae. Radial bands develop mostly during the adult stage, bands weakly salient, interband slightly depressed. Left valve flat, apparently acellular. Tooth "sockets" corresponding to grooved gutters. Anterior myophoral plate pediculate, long and thin, posterior rounded and short. Quadrangular microstructure present in the entire calcitic outer layer strongly elongated on the dorsal and anterior sides with some amoeboid portions (deflected growth laminae), short rectangular in the rest of the shell.

Comparison with other Eoradiolites species. Moving "Praeradiolites" ibizanus to the genus Eoradiolites necessitates comparison of this form with other described species of this genus, essentially those of the Albian-Cenomanian. Data from Table 1 and Fig. 9 indicate that the morphometry of E. ibizanus is close to that of Eoradiolites hedini (Douvillé). This Tibetan 
species differs from E. ibizanus in its subcylindrical shape, strongly lamellar shell habit, a subcircular transverse outline and a pronounced ribbed dorsal side. Additional comments, especially regarding similarities and dissimilarities with $E$. cantabricus and $E$. jumillensis nov. sp., all belonging to the E. cantabricus group, are given below.

Stratigraphical position. The stratigraphical position of rudistbearing limestones in which $E$. ibizanus was found has been revised by Fourcade et al. (1982). They overlie beds with Orbitolinopsis reticulata Peybernes and Moullade (late Gargasian) and are overlain by beds with Simplorbitolina chauvei Fourcade and Archaealveolina decastroi Fourcade. The position of the rudist beds is likely to be Clansayesian (see discussion of the micropalaeontological assemblages in Masse et al., 1992). Eoradiolites ibizanus has been documented only from its type locality.

\section{Eoradiolites jumillensis nov. sp.}

Figs. 13-19

1992 Praeradiolites sp., Masse et al. Pl. 4, figs. 9-10

1993 Praeradiolites sp.1, Gallo-Maresca, p. 82-84, pl. 10, figs. $1-3$, pl. 12 , figs. $1-2$

1998a Praeradiolites sp. 1, Masse et al., p. 206, fig. 13.4.

Derivation of name. After the city of Jumilla, adjacent to the Sierra del Carche, northern part of the Province of Murcia (SE Spain).

Type locality. Sierra del Carche (Fig. 12A) near Jumilla ( $1^{\circ}$ $\mathrm{O}^{\prime} 58^{\prime \prime}$ W/38 $26^{\prime} 16^{\prime \prime} \mathrm{N}$ ).

Holotype. Sample number 10940-1 which contains four transverse sections from a RV, is housed in the Centre de Sedimentologie-Paléontologie, Université de Provence, Marseille.

Paratypes. Seven specimens, selected as paratypes (sample numbers 10940-2 to 7) from the same bed as the holotype at Sierra del Carche and one from Sopalmo (12081).

Other materials. Six randomly oriented sections from field photographs.

State of material. The holotype and paratypes come from tight limestones and are represented by slabs. Sections were cut transversally and longitudinally in order to illustrate the corresponding shell organisation.

Type level. In the stratigraphic succession of the Sierra del Carche (Fig. 12B), Eoradiolites jumillensis nov.sp. is found with other rudists: Pseudotoucasia santanderensis (Douvillé), Caprotina sp., Agriopleura? darderi (Astre) and forms belonging to the Polyconites-Horiopleura group. The corresponding micropalaeontological assemblage is typified by Simplorbitolina manasi Ciry and Rat, indicative of the lowermost Albian (and uppermost Clansayesian?) (Masse et al., 1992). The specimen from Sopalmo comes from the same stratigraphic interval.
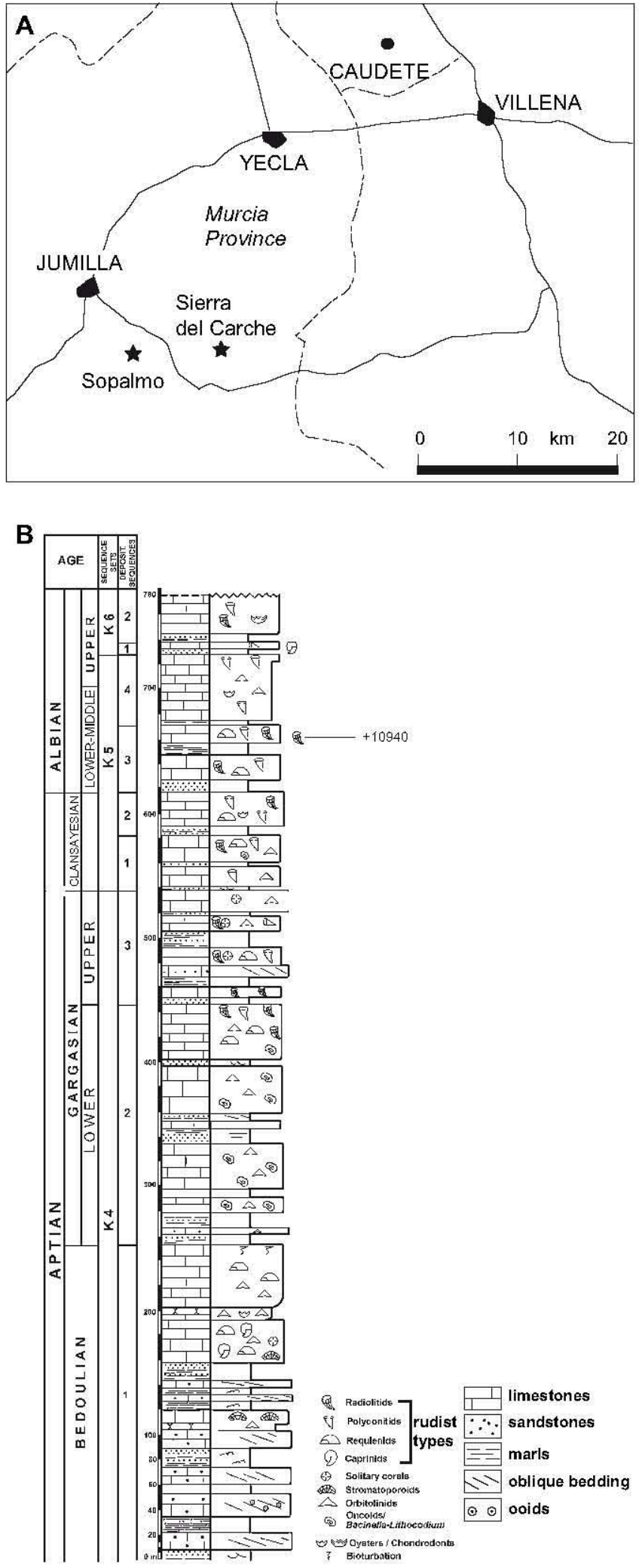

Fig. 12. Geographic and stratigraphic situation of the type locality of Eoradiolites jumillensis nov. sp., Sierra del Carche near Jumilla. A, location map of Sierra del Carche and Sopalmo. B, stratigraphic section of Sierra del Carche showing the position of sample 10940 (type material). 
Generic attribution. The convex outward structure and the salient geometry of the radial bands, coupled with a typical quadrangular shell microstructure assign this form to Eoradiolites.

Diagnosis. Relatively large, conical, moderately asymmetrical Eoradiolites with a subrectangular to triangular transverse outline, and strong lamellar banding rhythms. Growth laminae bent outward at juvenile stage then nearly flat, oblique to shell axis. Radial bands moderately salient, wide; short, acute, with depressed interband. Left valve flat, slightly convex centrally, extending to shell edge of the right valve, with a subconcentric, irregular, cellular microstructure. Tooth sockets modified as gutters at adult stage. Ligament ridge pediculate, cellular. Myophoral plates subequal. Quadrangular microstructure of right valve present in the entire calcitic outer shell layer, elongation depending on the obliquity of shell laminae to shell axis, presence of polygonal cells within the anterior band.

\section{Description}

Macroscopic aspects. The right valve is conical (Fig. 13) (h/ $\mathrm{d}=1.1-1.2$ in holotype), lamellar, with a subrectangular
(Fig. 13) to subtriangular (Fig. 15) outline, and a moderate antero-posterior compression, dDV $(8-10 \mathrm{~cm})$ being longer than dAP $(7-7.5 \mathrm{~cm})$ (holotype $\mathrm{dAP}=7 \mathrm{~cm}, \mathrm{dDV}=8 \mathrm{~cm}$ ).

Growth laminae are bent outward during the juvenile stage, but at the adult stage this trend disappears, hence growth laminae are more regularly oblique to the shell axis (Fig. 14). The modification from the juvenile to the adult mode of growth is abrupt (Fig. 13G) and coupled with a moderate growth allometry, i.e. the anterior side records a decrease in dilatation (in the sense of Ackerly, 1989). A striking feature is the rhythmic pattern of shell growth manifested by the arrangement of growth plates (i.e. sets of growth laminae). The left valve is flat, thin, slightly convex anteriorly, and covers the expanded shell margin of the right valve, the outer margin is slightly elevated upward in correspondence to the inward slope of the opposite valve (Fig. 13G). The ligament ridge is triangular, pediculate (Fig. 13A-E).

Transverse sections (Figs. 13, 15, 16, 17) show that growth laminae have a crescentric architecture: some dorsal elements pinch-out on the postero-dorsal side (Fig. 17), conversely some ventral elements may pinch-out on both anterior and posterior sides (Fig. 13). This geometry does not strictly conform to that of fitted truncated inverted cones expected from
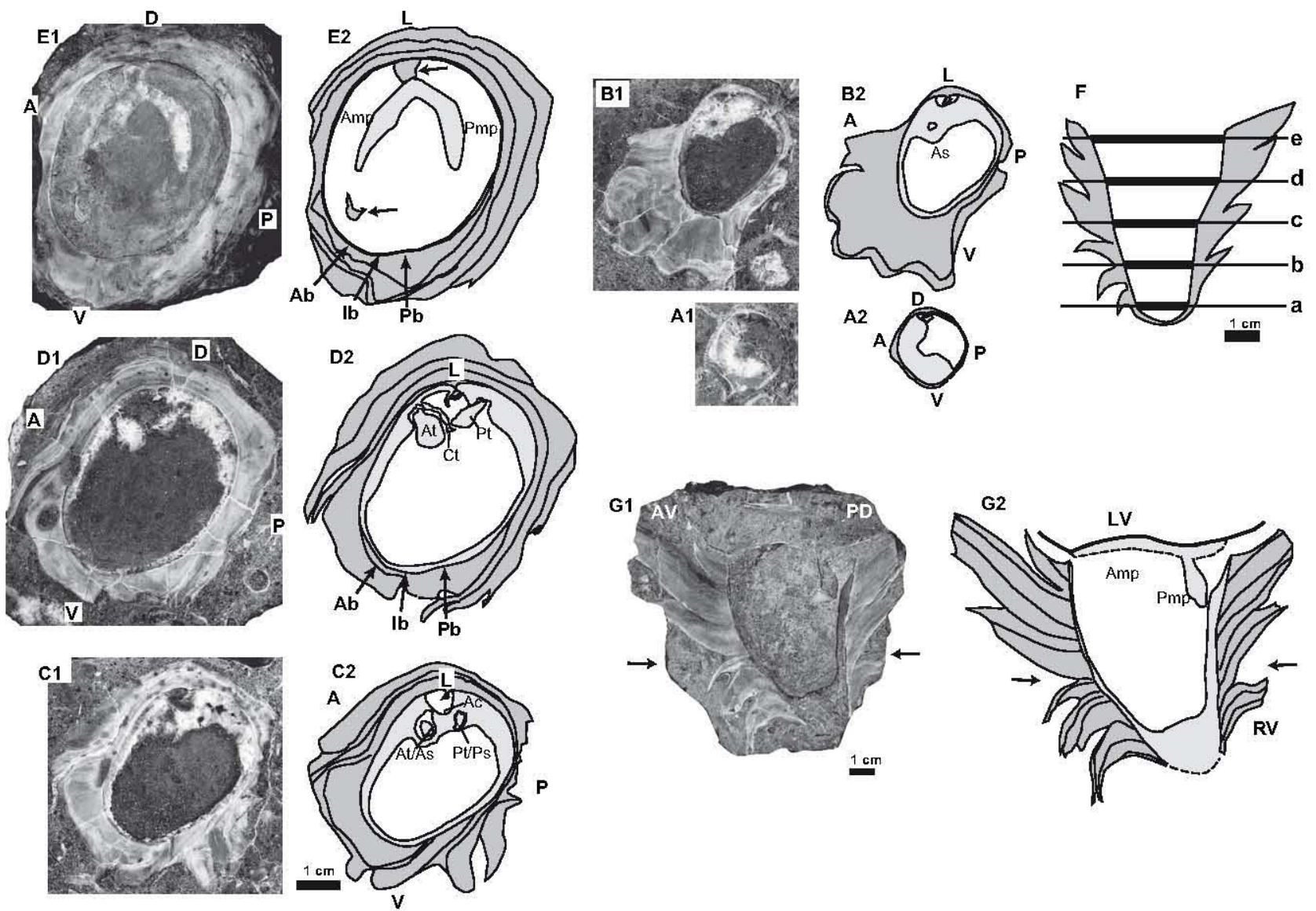

Fig. 13. Eoradiolites jumillensis nov. sp. RV, serial transverse sections cut in the holotype (10940-1, H1-4) (A-E) showing the external and internal changes from the juvenile stage (A) to the adult stage (E) and the position of the sections on the longitudinal sketch reconstruction (F). Small arrows (E2) point to remnants of the LV and large arrows show the position of the radial bands (D2, E2). Longitudinal section (AV-PD) of a paratype specimen (10940-2) showing the abrupt modification (arrows) from deflected to oblique growth plates and the flattened LV bearing the posterior myophoral plate and extending to the shell edge of the RV (G1, G2). 


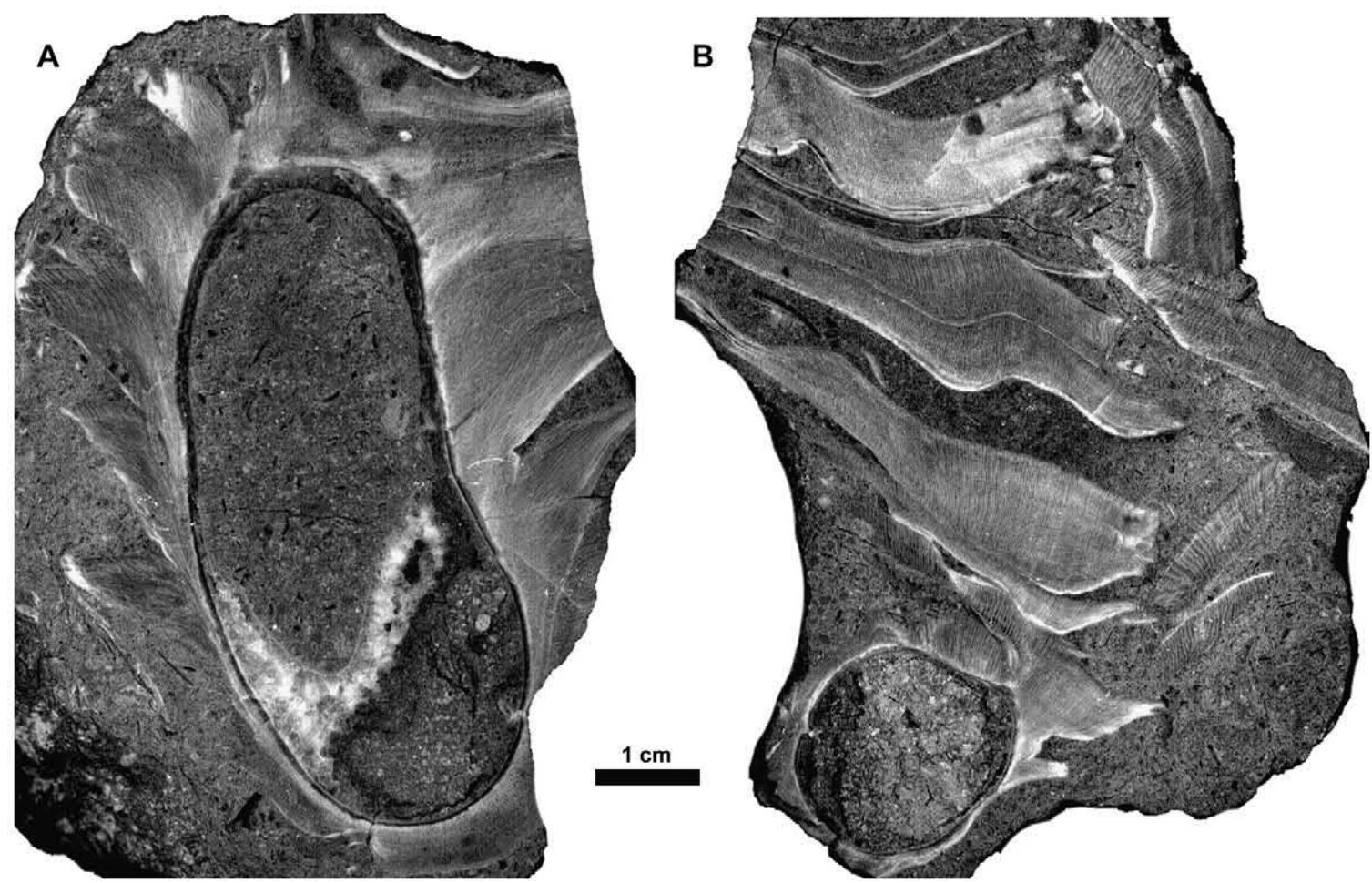

Fig. 14. Eoradiolites jumillensis nov. sp. RV, shell growth patterns. a, longitudinal oblique section (10940-5) showing growth banding. b, same individual cut obliquely to show the juvenile stage, and tangentially to illustrate growth banding.

longitudinal axial sections (e.g. Fig. 13F, G) and may relate at least in part, to the deflection of growth laminae described above, or to the concave or convex upward geometry of the shell edge.

From the juvenile to the adult stage tooth sockets modify to gutters, and the central tooth becomes lamellar, oblique to the shell wall (Fig. 13C, D, E). The myophoral plates extend from the dorsal side approximately to a line obliquely crossing the shell in its middle (Figs. 13E, 17): they are nearly transversally, equally developed. They appear to be slightly divergent from their base of attachment (Fig. 13G) a result of conical shell growth (see discussion of E. cantabricus). On the ventral side $\mathrm{Ab}$ and $\mathrm{Pb}$ are nearly equal in width; $1-1.3$ and, 1$1.4 \mathrm{~cm}$ respectively, and separated by a narrow $(0.5-0.8 \mathrm{~cm})$ depressed $\mathrm{Ib}$ (Figs 13D, E, 15, 16). The corresponding growth laminae are convex outward. Ab may fuse with the ventral carina (Fig. 17).

Microscopic aspects. Shell microstructure of the right valve is typically quadrangular, rectangular or square (Figs. 16, 17) on the dorsal side, rectangular elongated where growth laminae bend outward (due to undulations of funnel plates) (Fig. 18A). The cellular structure records some periodical changes in radial elongation (Fig. 18A) which may reflect changes in orientation of growth laminae to the shell axis and/or seasonal growth banding. The inner portion of the shell is characterized by a radial branching habit, with bifurcated walls oriented towards the body cavity (Fig. 18B). This structure, which grades outward to a rectangular pattern, is equivalent to that of Archaeoradiolites nov. gen. (Fenerci-Masse et al., 2006), which is regarded as the ancestor of Eoradiolites. Therefore E. jumillensis nov. sp. records in its juvenile stage some plesiomorphic characters. The microstructure of $\mathrm{Ab}$ shows polygonal cells (Fig. 18C) closely resembling those of Praeradiolites (Amico, 1977). Radial walls tend to be shorter and more vigorous close to the cortical layer (Fig. 18D). The ligament ridge is cellular (Fig. 19A). The left valve also illustrates a cellular structure that departs from the rectangular mode of the opposite valve. Tangential sections show wavy irregular plates with an overall concentric organisation (Fig. 19B), locally connected by short radial walls (Fig. 19C).

Comparison with other species. Morphometric attributes of E. jumillensis nov. sp. (dAP, $\mathrm{dDV}$ and $\mathrm{h} / \mathrm{d}$ ) are close to those of E. cantabricus (Table 1 and Fig. 9), the two species forming a group of low conical and large forms, compared to the other Aptian-Albian and Cenomanian representatives of Eoradiolites. Hence comparisons will concentrate on similarities and to differences from the Cantabrian form. Besides some morphometric dissimilarities, the most striking differences between $E$. jumillensis nov. sp. and $E$. cantabricus are: (1) a stronger lamellar shell habit in E. jumillensis nov. sp., with a well defined, rhythmic growth banding; (2) a distinctive ontogeny characterized by a juvenile stage with deflected growth laminae followed by a more regular funnel plate mode of growth. The growth laminae angle to the shell axis tends to increase with size. This is the reverse of E. cantabricus; (3) the cellular structure of the ligament ridge; (4) the polygonal structure of $\mathrm{Ab} ;(5)$ the architecture of the left valve and (6) the cellular structure and shape. 

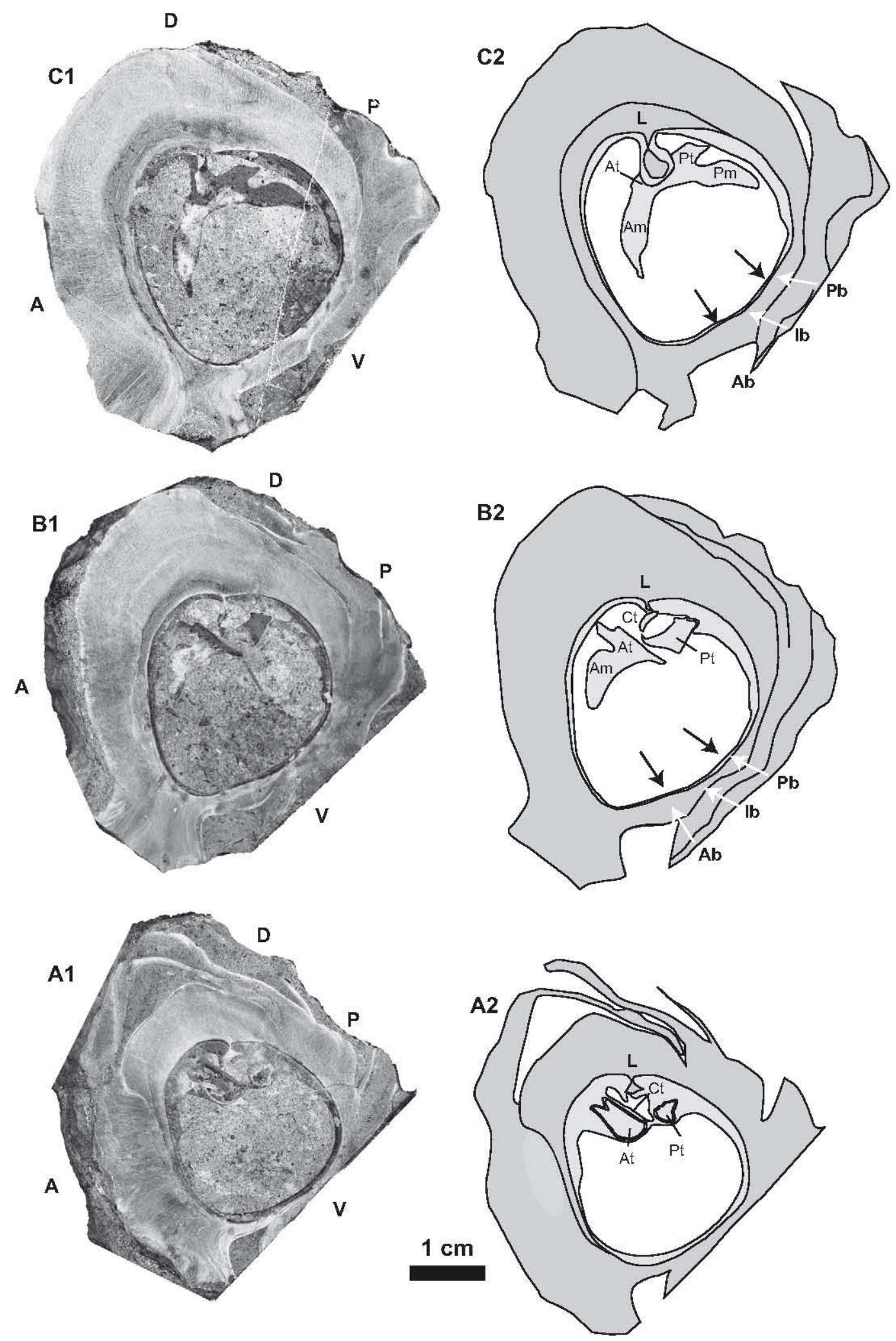

Fig. 15. Eoradiolites jumillensis nov. sp. Paratype (10940-3). RV, adapical serial transverse sections showing the morphological changes of the myocardinal elements through ontogeny (A to $\mathrm{C}$ : apex to commissure). Arrows point to flattened areas of the inner shell margin facing the radial bands. 


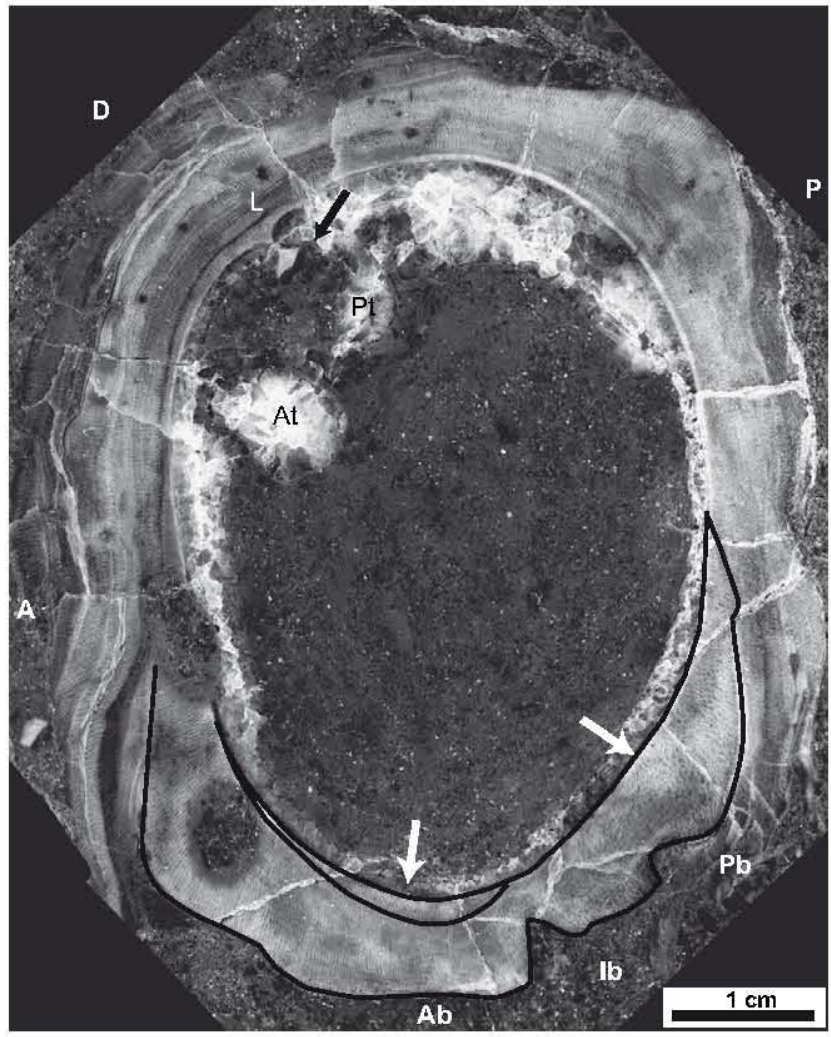

Fig. 16. Eoradiolites jumillensis nov. sp. RV, transverse adapical section (closeup of Fig. 13D) showing the overall shell organisation, radial bands and spatial variations of the cellular microstructure in correspondence with the different portions of the shell (see comments in text). White arrows point to flattened areas of the inner shell margin facing the radial bands and the black arrow shows the ligament.

Additional differences, especially regarding similarities and dissimilarities with E. ibizanus (Astre) and E. cantabricus are given below.

\section{Praeradiolites sp.}

Fig. 20

1907 Sphaerulites cantabricus Douvillé, Toucas p.11, fig. 3 1954 Sphaerulites cantabricus Douvillé, Astre, p.93-94.

Relationships between "Sphaerulites cantabricus" (Douvillé) sensu Toucas (1907) and Eoradiolites cantabricus (Douvillé):

When ascribing "Praeradiolites" cantabricus (Douvillé) to the genus Sphaerulites, Toucas (1907) did not refer to the type figure from Douvillé (1889), but to the transverse section of a specimen from the same locality (Portugalete). According to Toucas, this form is marked by the presence of two inflated areas in the inner portion of the postero-ventral zone facing depressed zones of the outer shell, interpreted as radial bands here labelled $\mathrm{Ab}$ and $\mathrm{Pb}$, and corresponding to foliated, folded growth band, posteriorly. This description draws attention to the significant folding of the radial bands which is not included in Douvillé's original description of "Radiolites" cantabricus, as well as to the inflated inner shell zone. Hence Toucas' figure appears unlikely to correspond to Douvillé's taxon.

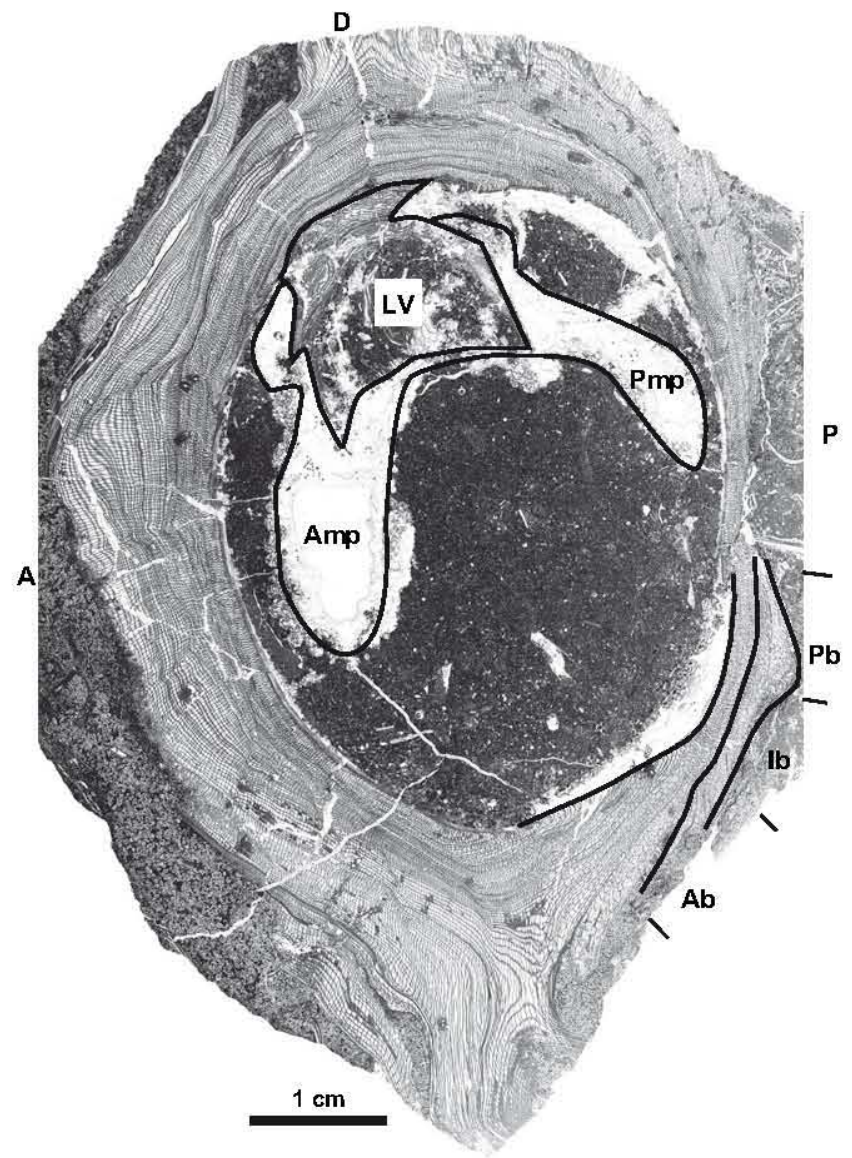

Fig. 17. Eoradiolites jumillensis nov. sp. (Sopalmo, sample 12081). Transverse section (thin section) of the RV showing the myophoral plates, remnants of the LV in dorsal side, the radial bands, and their microstructural aspects.

Revision of the type material of "Sphaerulites cantabricus" Douvillé sensu Toucas (1907). The specimen figured by Toucas (p.11, fig. 3) is housed in the Centre commun des collections de géologie (Université Claude Bernard, Lyon 1). Toucas' figure illustrates an oblique transverse section of the $\mathrm{RV}$ in which the position of the radial bands ( $\mathrm{Ab}$, and $\mathrm{Pb}$, ) and the myophoral plates are indicated. This section is viewed from the apex toward the commissure of the right valve (abapical) so the orientation proposed by Toucas for the radial bands and the myophores is not correct: the anterior side is actually the posterior side and vice versa. The specimen is not only a slab but bears a significant part of the left valve plus the right valve (Fig. 20B), allowing examination of both significant external and internal characters. The section (Fig. 20A1, A2) shows that the ligament ridge is destroyed and the myophoral plates as well, whereas the teeth of the left valve are well preserved in situ, in the sockets of the right valve, the anterior one being larger than the posterior. The body cavity is strongly tabulated (Fig. 20A1, A2). Slightly convex inward though nearly flat "bulges" are present at the inner ventral margin of the calcitic outer shell layer. The corresponding radial bands are marked by concave outward growth lines, the posterior ones being nearly circular, facing depressions of the shell. The interband is salient and also marked by concave outward growth plates. The shell microstructure fluctuates in correspondence 

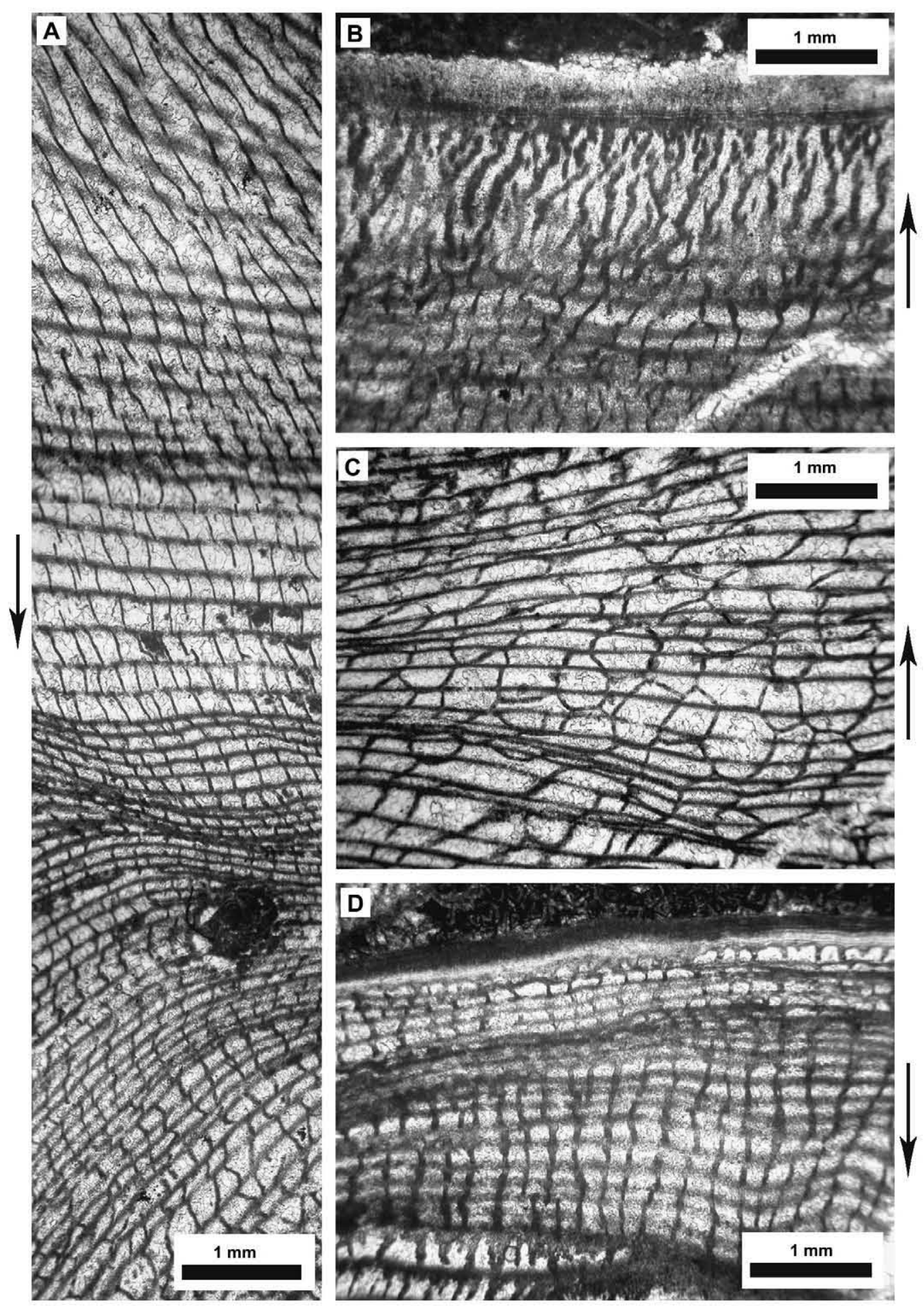

Fig. 18. Eoradiolites jumillensis nov. sp. (close-up of Fig. 17). Microstructural aspects. A, radial section showing variously elongated quadrangular cells related to growth banding and/or variations in the orientation of growth laminae to the shell axis. B, branching radial walls flanking body cavity. C, polygonal cellular habit associated with $\mathrm{Ab}$. $\mathrm{D}$, reduction in thickness of growth laminae close the cortical layer (arrows show the direction of the body cavity).

to the different shell areas, from rectangular to polygonal (e.g. dorsal side, Fig. 20C).

The left valve is convex, the beak is bent dorsally (even broken), the commissure is undulated and its location hard to identify in the overall lamellar habit of the shell (Fig. 20B). The ventral side view of the right valve shows the strongly folded convex upward radial bands, the anterior being wider than the posterior, separated by the concave upward interband (Fig. 20B).

The foregoing description of Toucas' material shows that various features argue against assignment to Sphaerulites, including: (a) the overall shell habit, mainly the absence of flattening, (b) growth laminae: widely undulating and not bent outward, (c) the shape of the inner ventral shell margin which 

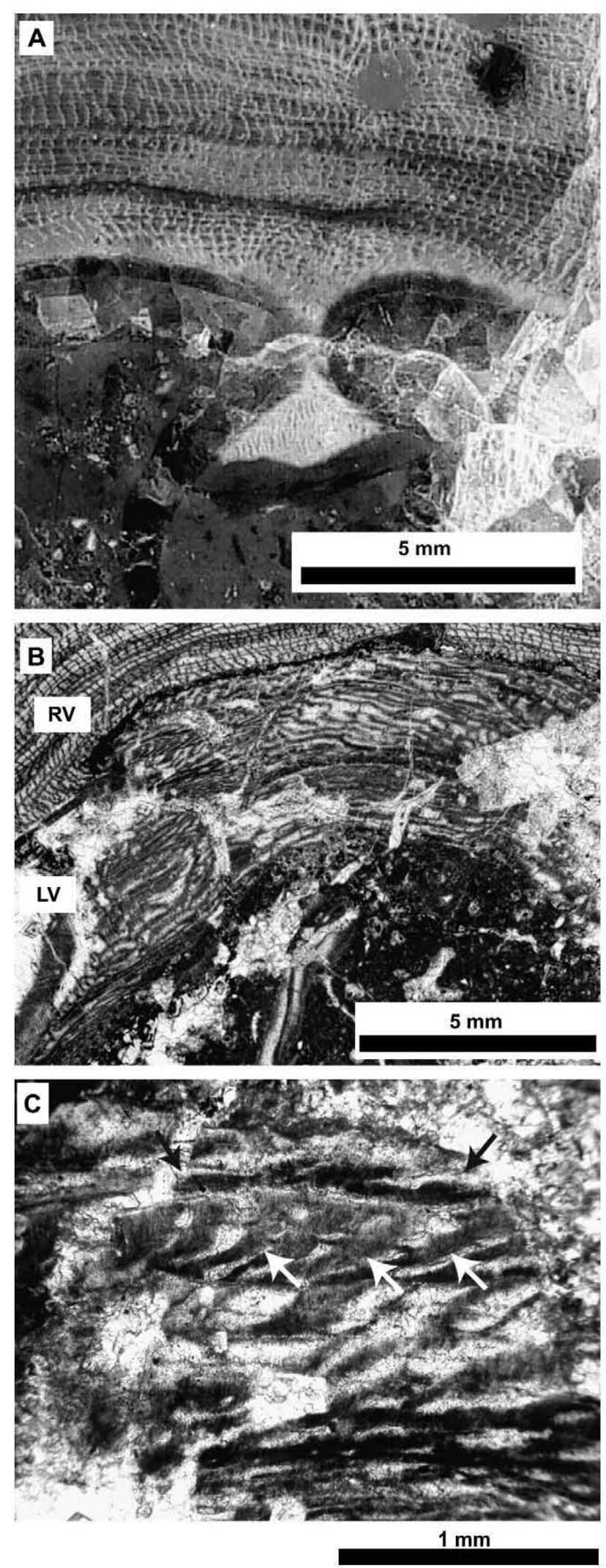

Fig. 19. Eoradiolites jumillensis nov. sp. A, transverse section of the ligament ridge with a cellular microstructure (close-up of Fig. 16). Microstructural aspects of the LV(close-up of Fig. 17). B, tangential section of the dorsal side showing the wavy concentric habit of plates. C, close-up of the preceding showing radial walls (white arrows) connecting the plates (black arrows). does not conform to those of Sphaerulites, marked by welldefined convex inward protrusions; flattening of the inner ventral margin, facing the radial bands, is a common feature in the Radiolitidae, e.g. Eoradiolites, for example E. hedini Douvillé (Douvillé, 1916) and species described in the present paper.

To conclude, "Sphaerulites cantabricus" sensu Toucas possesses the diagnostic attributes of the genus Praeradiolites, mainly the configuration of ventral radial bands and shell microstructure.

Regarding shell size, shape of the left valve and folding of the radial bands, this form strongly differs from the representatives of Praeradiolites documented so far from the AlbianCenomanian. Species from Asia are problematical and tend to be acellular (Masse and Gallo-Maresca, 1997). American forms are poorly documented, e.g. Praeradiolites sp. Coogan, 1977 (p.7, figure 6a-b) and Praeradiolites ? edwardsensis (Adkins) (Coogan, 1977). Forms from the Mediterranean area recorded in the Cenomanian, including Praeradiolites biskraensis (Coquand), P. fleuriaui, (d'Orbigny), $P$. pironai Parona and $P$. sinaiticus Douvillé, are essentially smaller, with weak ventral folds and a nearly flat LV (at least for those forms where this valve is known). Actually, the taxonomic affinities of Praeradiolites sp. are with advanced forms of the Praeradiolites cylindraceus (Des Moulins) group in the sense of Toucas (1907), especially P. requieni (d'Hombres Firmas), a Coniacian taxon (Toucas, 1907; Sanchez, 1981). This suggests two possibilities: either Praeradiolites sp. represents some kind of Albian evolutionary precursor without descendant or the taxon in question came from beds younger than the Albian, i.e. late Cretaceous. Considering that it was obtained by Toucas from the de Verneuil collection, the second hypothesis is more likely and implies that Praeradiolites sp. must be transferred from the Early to the Late Cretaceous fauna.

\section{Discussion}

Variability is undoubtedly the major weakness in the definition of the foregoing Eoradiolites species, particularly with regard to the outer shell outline. Several lines of evidence suggest that the external shell morphology of radiolitids is influenced by environmental perturbations during their growth history, including substrate mobility induced by water agitation or bioturbation and sedimentation rate (Steuber et al., 1998). A key factor is the gregarious mode of life leading individuals to grow in mutual contact.

Neverthless, morphometric analysis of 23 AptianCenomanian species (Table 1 and Fig. 9) based on quantitative attributes, submitted to regression analysis provide meaningful positive correlations between $\mathrm{d}$ and $\mathrm{h}$ of the holotypes $(\mathrm{n}=23$, $\mathrm{r}=+0.54, \mathrm{p}=0.0073)$ and shows the specificity of the Eoradiolites cantabricus group.

In addition Table 2 illustrates various aspects of the three species in question including macroscopic (radial bands, myophores, shell morphology and architecture) and microscopic aspects, mainly the cellular structure. E. ibizanus is typified by the peculiar morphology of it myophoral plates, especially 

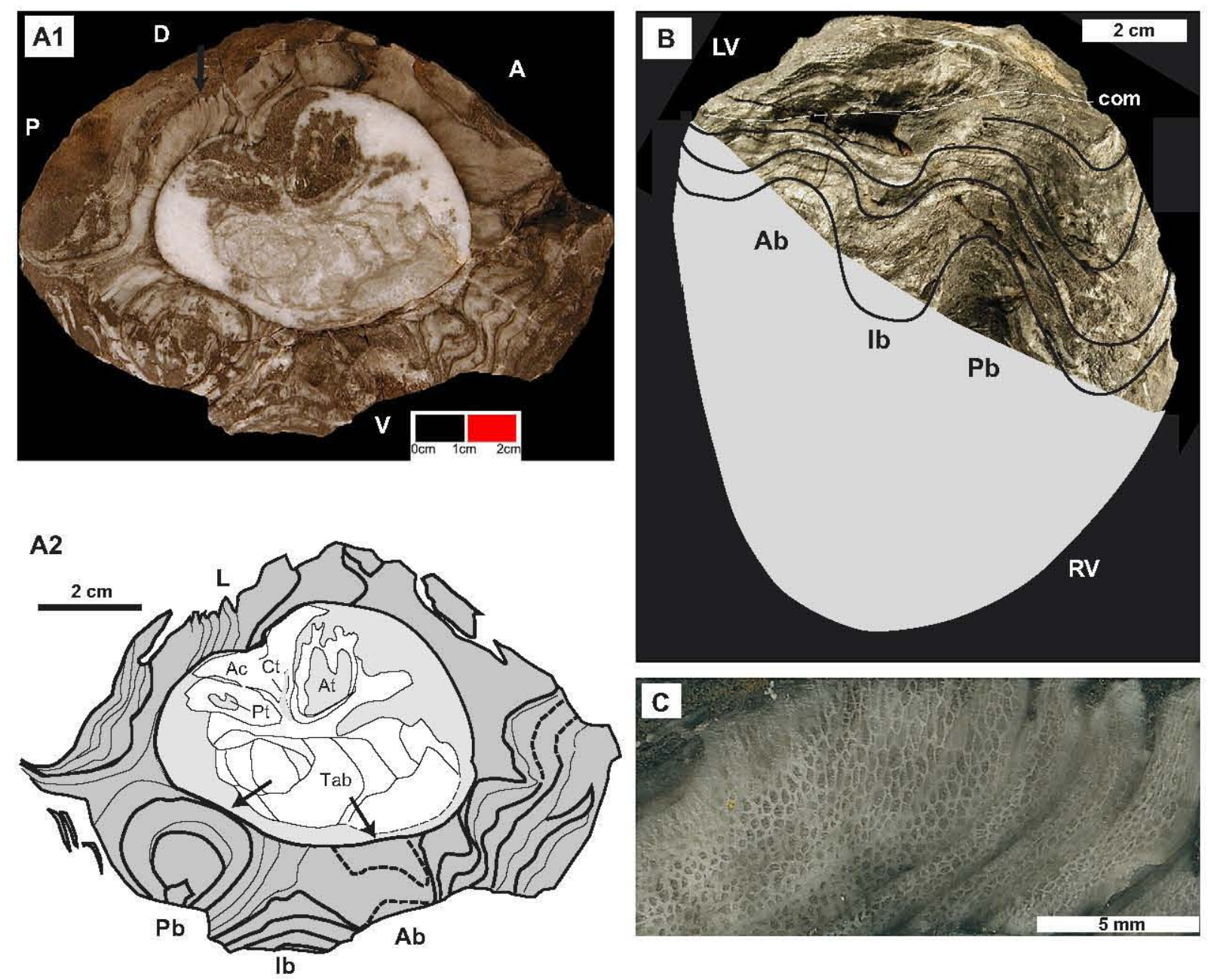

Fig. 20. Praeradiolites sp. Portugalete (pro Sphaerulites cantabricus Douvillé, in Toucas, 1907). A1, RV, transverse oblique abapical section equivalent to figure 3 in Toucas, 1907 , arrow points to the place of figure C. A2, interpretation of the myocardinal elements and the radial bands, arrows point to slightly convex inward/ flattened areas from the inner shell margin facing the radial bands. B, ventral view showing the organisation of the radial bands and the shape of the LV (com, commissure). C, close-up of the dorsal side showing the polygonal/amoeboid cellular network.

the anterior one, growth mode and the morphology of the radial bands appear also specific, whereas the cellular habit of the right valve and the apparent compact structure of the left valve are nearly identical to those of E. cantabricus. E. cantabricus is typified by the morphology of its radial bands, the ontogenic variations of growth plates, the geometry of myophoral plates and a peculiar mode of commissural junction between the two valves, besides the geometry of its radial bands. E. jumillensis nov. sp. is typified by the ontogenetic variation of growth plates, growth mode, the presence in the $\mathrm{Ab}$ of polygonal cells, the cellular structure of the ligament ridge and the peculiar cellular microstructure of the left valve and its mode of commissural junction with the right valve.

\section{Implication for the evolutionary state of late Aptian- Albian Radiolitidae and their biostratigraphical and palaeobiogeographical significance}

The foregoing results show that Sphaerulites and Praeradiolites cannot apply to pre-Cenomanian radiolitids from the
Mediterranean region. Eoradiolites and Durania are the only genera documented from the late Aptian-Albian of this region. "Durania" praeblayaci Polsak and Azema (Polsak and Azema, 1969) is characterized by the absence of a ligament ridge but does not strictly conform to the other diagnostic attributes of the genus, i.e. polygonal cellular network and annular mode of shell growth, and may belong to a distinct generic entity. The only unequivocal species of Durania is D. delphinensis Moret (Moret, 1936) from the latest Albian (Vraconian) of the Grenoble region (SE France). Hence Eoradiolites is the main genus accounting for species diversity during the time span in question. Our taxonomic reappraisal of radiolitid species including Praeradiolites cantabricus and $P$. ibizanus, to be transferred into Eoradiolites, and the erection a new species of this genus, $E$. jumillensis nov. sp., result in a 33\% increase in species diversity of the genus Eoradiolites (from 6 to 9 species) during the late Aptian-Albian. Compared to Eoradiolites plicatus, E. katzeri, E. liratus, E. rousseli and E. murgensis, the group of species including Eoradiolites cantabricus, E. ibizanus and E. jumillensis nov. sp., i.e. the 


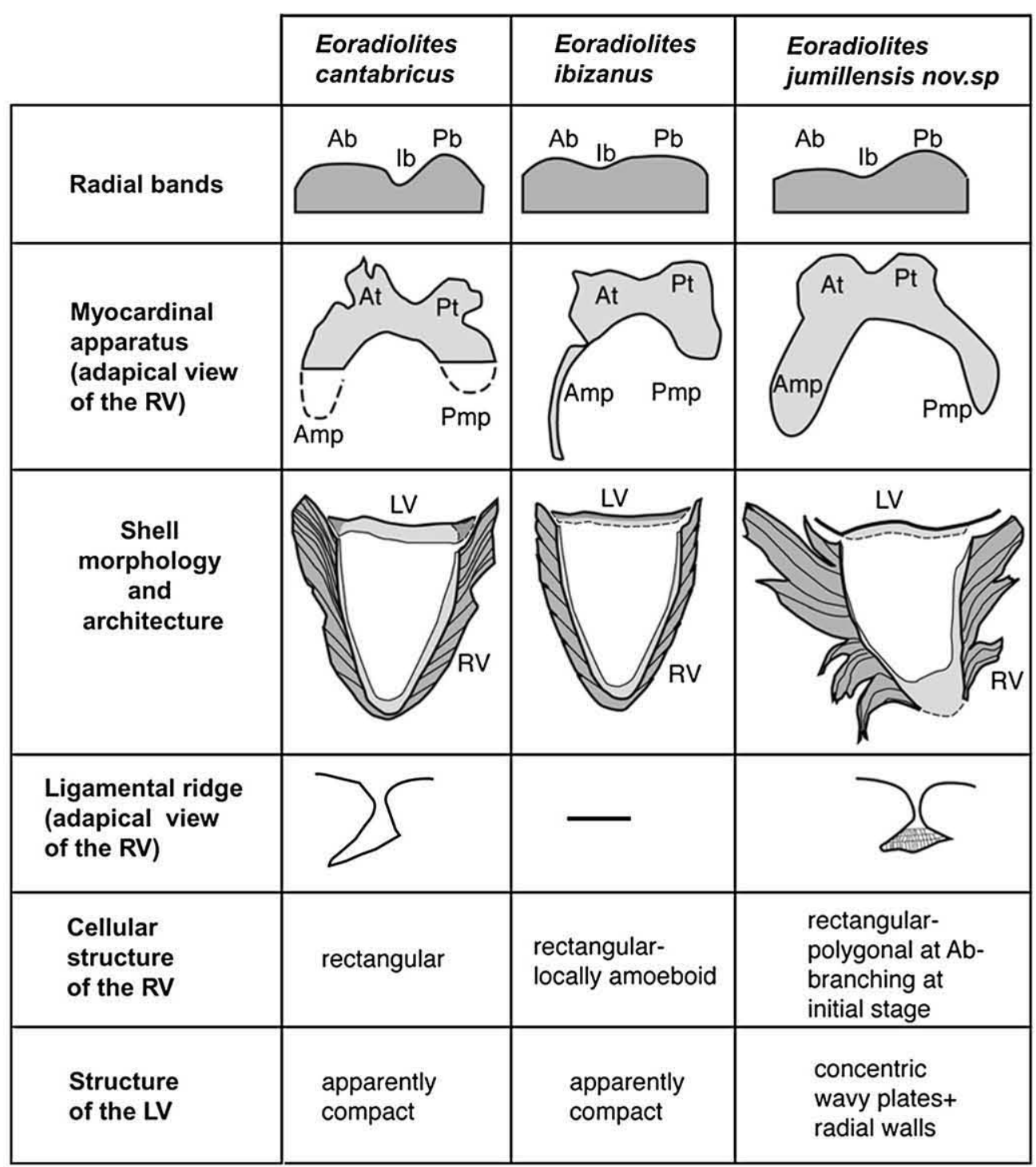

$E$. cantabricus group, shows a set of distinctive characters including: (1) a relatively large size: this is mainly true for $E$. cantabricus and E. jumillensis nov. sp., and expressed by a relatively large commissural diameter, (2) cellular structures are developed in the entire shell: this pattern contrasts with, for instance, the partial cellular character of Eoradiolites plicatus, $E$. katzeri, E. liratus, E. metohiensis and E. rousseli (personal observations) whereas in $E$. murgensis cells are present in the entire outer shell (Torre, 1965; Gallo-Maresca, 1993). The existence of amoeboid ( $E$. ibizanus) or polygonal structures (E. jumillensis nov. sp.) document some advanced evolutionary state (Amico, 1977) whereas some plesiomorphic characters, e.g. branching structures of $E$. jumillensis nov. sp. are still maintained, (3) a pediculate ligament ridge, whereas in Eoradiolites plicatus and $E$. katzeri this feature is triangular and (4) tooth sockets changing with ontogeny into gutters with sliding grooves: this cardinal mode is usually found in AlbianCenomanian taxa (e.g. E. davidsoni).
The acquisition of a low conical morphology appears to be a typical feature of $E$. cantabricus and $E$. jumillensis nov. sp. Based on shape similarities with the modern solitary coral Manicina areolata (Linnaeus) (Hubmann et al., 2002) this shape might have been advantageous for the two radiolitid species for remaining in upright position under the influence of bottom water currents through "passive digging" behaviour. This behaviour is controlled by the interplay of sediment erosion or accumulation and the shell posture in the immediate vicinity of the semi-buried individual (Hubmann et al., 2002).

All these features document a relatively advanced evolutionary state for the E. cantabricus group, compared to other contemporaneous species. Within the group, E. cantabricus has the higher evolutionary state (=the more advanced) and $E$. ibizanus the lower, E. jumillensis nov. sp. being in between the former species ( $E$. cantabricus et $E$. ibizanus). This advanced group, which evolved in the Clansayesian-Early 
Albian of the European Province (Masse and Gallo-Maresca, 1997), recorded a significant size increase relative to its ancestors (mainly E. plicatus). This phenomenon, which conforms to Cope's rule (Jablonski, 1996), has been reported in many rudist lineages, e.g. in the Caprinidae and Hippuritidae (Skelton, 1994; Skelton and Masse, 1998; Steuber, 2003). From a phylogenetic point of view the juvenile stage of $E$. cantabricus mimics the adult stage of Sphaerulites. Hence paedomorphosis (sensu McNamara, 1986) might be a clue to the understanding the phyletic derivation of Sphaerulites from $E$. cantabricus, or a closely related form. Likewise the juvenile stage of $E$. jumillensis nov. sp. (with deflected outward growth plates + polygonal cellular structure in the $\mathrm{Ab}$ of the right valve) mimics Praeradiolites, hence paedomorphosis might be again, in this instance, a clue for understanding the phyletic derivation of Praeradiolites from E. jumillensis nov. sp. or a closely related form. Owing to the small size of the first representatives of Cenomanian Praeradiolites (e.g. P. fleuriaui, $P$. biskraensis) relative to lower Albian forms, the above postulated phyletic mode must have been coeval with progenesis (sensu McNamara, 1986). The foregoing examples suggest that paedomorphosis may have been important in rudist evolution, as previously noticed by Skelton (in Gourrat et al., 2003). Our hypotheses concerning the phyletic derivation of Praeradiolites and Sphaerulites from Eoradiolites conforms to those of Douvillé (1910, 1913b). The disappearance at the AlbianCenomanian transition of large forms belonging to Eoradiolites (the E. cantabricus group) which is nearly coeval with the onset of (large) Sphaerulites (e.g. S. foliaceus), suggests an ecological replacement.

The foregoing results give some clue for distinguishing Clansayesian-Lower Albian faunas from their Gargasian and Middle-Upper Albian homologues. Gargasian forms are dominated by species belonging to Archaeoradiolites nov. gen., associated with few poorly documented Eoradiolites (FenerciMasse et al., 2006). The Eoradiolites cantabricus group differs from coeval species found in Apulia (Gallo-Maresca, 1993; Masse et al., 1998b) and the Middle East (Skelton and Masse, 2000; Steuber and Bachmann, 2002), all belonging to the Arabo-African Province (Masse and Gallo-Maresca, 1997) of the southern Tethyan margin.

\section{Conclusions}

Late Aptian-Albian Radiolitidae from SW France and Spain formerly known as Praeradiolites cantabricus and $P$. ibizanus are transferred to Eoradiolites. A new species of this genus formerly ascribed to Praeradiolites, Eoradiolites jumillensis nov. sp., is described from southern Spain. Contrasting patterns in shell growth mode, ontogeny, myophoral organization, radial bands and shell microstructure are found in the three species. Eoradiolites ibizanus is a Clansayesian species, E. cantabricus extends from Clansayesian to lower Albian (perhaps upper Albian?) whereas the type level for E. jumillensis nov. sp. is lower Albian. The so-called Sphaerulites cantabricus figured by Toucas (1907) belongs to
Praeradiolites with an evolutionary state close to Coniacian representatives of the genus. For that reason and because the geographical/stratigraphical origin of the study specimen cannot be indisputably confirmed we propose to exclude the form in question from the Early Cretaceous faunas. Including in Eoradiolites the three forms previously placed in Praeradiolites raises the specific diversity of the former genus by $33 \%$ and makes it the main genus contributing to radiolitid biodiversity in the late Aptian-Albian interval. Moreover, the first appearance of Sphaerulites and Praeradiolites must be moved to the Cenomanian. Eoradiolites cantabricus, E. jumillensis nov. sp. and, to a lesser extent, E. ibizanus form a group, the $E$. cantabricus group, with a set of distinctive characters including: large size, well-developed cellular shell structures, pediculate ligament ridge and tooth-sockets modified in gutters. The acquisition of a low conical shape may have been advantageous for remaining in upright position in an active water agitation regime. All these features are indicative of an advanced evolutionary state compared to the Eoradiolites plicatus-katzeri group, and, through size increase, conform to Cope's law. Through paedomorphosis, Praeradiolites may derive from $E$. jumillensis nov. sp., while E. cantabricus may be the root of Sphaerulites. The disappearance of large forms of Eoradiolites coincided with the onset of Sphaerulites in early Cenomanian times. The E. cantabricus group has a potential for recognizing the Clansayesian-Late Albian interval. It shows pronounced dissimilarities with its coeval forms from the peri-Adriatic domain, North Africa and the Middle East, and typifies under the present state of our knowledge, the northwestern Mediterranean Tethyan margin.

\section{Acknowledgements}

For access to, and information concerning specimens in their care, we are most grateful to M. Abel Prieur (Centre commun des collections de géologie, Université ClaudeBernard, Lyon1), M. Michel Bilotte (Collection de Paléontologie, Université Paul Sabatier, Toulouse) and J. Philip (Collection de Paléontologie, Centre Saint-Charles, Université de Provence, Marseille). We thank also the Société géologique de France for permission to reproduce the original figures from Douvillé and Toucas. Our field investigation in southern Spain have been founded by the Ministerio de Ciencia y Tecnologia of Spain, number of project: REN2001-1067/GLO (Aplicacion de tecnicas del analisis de cuencas sedimentarias en el uso no destructivo del patrimonio natural en al Prebetico oriental. El altiplano de Jumilla-Yecla). At the Université de Provence, we have benefited from the technical assistance of A. Arnoux. Fruitful discussions with L. Villiers (Université de Provence, Marseille) were greatly appreciated. K. Fernandez Mendiola (Basco-Cantabrian University of Bilbao, Spain) is thanked for his relevant informations concerning the rudistbearing locality of Portugalete. The authors gratefully acknowledge constructive reviews by P.W. Skelton (Open University, Milton-Keynes) and an anonymous reviewer. 


\section{References}

Ackerly, S.C., 1989. Kinematics of accretionary shell growth with examples from brachiopods and molluses. Paleobiology 15 (2), 147-164.

Amico, S., 1977. Etude de la structure du test des rudistes. Applications à la systématique à la paléobiologie et à la paléoécologie de ce groupe. Unpublished thesis, University of Marseille-Provence, $90 \mathrm{pp}$.

Astre, G., 1931. Sur une faune de rudistes du Crétacé des plateaux sahariens au Sud de l'Atlas marocain (vallée de l'Oued Ziz). Etude paléontologique. Bulletin de la Societe d'Histoire Naturelle de Toulouse 61, 345-355.

Astre, G., 1935. Un praeradiolitidé de l'ile d'ibiza. Proceedings of the Koninklijke Akademie van Wetenschappen te Amsterdam 38, 89.

Astre, G., 1954. Radiolitidés nord-pyrénéens. Société Géologique de France Mémoires 71, 1-140.

Bataller-Calatayud, J.R., 1947. Sinopsis de las especies nuevas del Cretacico de Espana. Memorias Real Academia de Ciencias y Artes Barcelona 3, 279-484.

Bobkova, N.N., 1974. Upper Cretaceous rudists from the south-western part of central Asia. Trud. Vses. Nauk. Issled. Slog. Geol. Inst. (in Russian), 196 pp.

Böggild, O.B., 1930. The shell structure of the mollusks. Det Kongelige Danske Videnskabernes selskrabs Skrifter, Naturvidenskabelig og Mathematisk Afdeling 2, 235-326.

Caffau, M., Plenicar, M., 1991. Rudistid fauna from Turonian deposits of the locality "Archi" $/$ Moscenice in the surroundings of Duino (Karst of Triest). Razpr. Razred. Saz. 32 (8), 259-315.

Coogan, A.H., 1977. Early and Middle Cretaceous Hippuritacea (Rudists) of the Gulf Coast. In: Bebout, D.G., Loucks, R.G. (Eds.), Cretaceous carbonates of Texas and Mexico. Application to surface exploration. Bureau of Economic Geology, Report of Investigation 89, pp. 32-70.

Dechaseaux, C., Cox, L.R., Perkins, B.H., 1969. Superfamily Hippuritacea Gray 1848. In: Moore, R.C. (Ed.), Treatise on Invertebrate Paleontology, Part N, Mollusca 6, Bivalvia, 2. University of Kansas, Lawrence Kansas and Geological Society of America, pp. N749-N817.

Douvillé, H., 1889. Sur quelques rudistes du terrain crétacé inférieur des Pyrénées. Bulletin de la Société géologique de France 3, 627-653.

Douvillé, H., 1900. Sur quelques rudistes americains. Bulletin de la Société géologique de France 3 (28), 205-221.

Douvillé, H., 1902. Classification des radiolites. Bulletin de la Société géologique de France 4 (2), 461-477.

Douvillé, H., 1909. Sur le genre Eoradiolites nov. Bulletin de la Société géologique de France 9, 1-77.

Douvillé, H., 1910. Etudes sur les rudistes. Rudistes de Sicile, d'Algérie, d'Egypte, du Liban et de la Perse. Bulletin de la Société géologique de France, Mémoir 41, 1-83.

Douvillé, H., 1913a. Description des rudistes de l'Egypte. Mémoires de l'Institut Égyptien 6, 237-256.

Douvillé, H., 1913b. Sur quelques rudistes du Liban et sur l'évolution des Biradiolitidés. Bulletin de la Société géologique de France 4, 409-421.

Douvillé, H., 1916. Les calcaires à Orbitolines et à Radiolites du Thibet. In: Hedin, S. (Ed.), Discoveries in Former Times Compared with My Own Researches in 1906-1908, 5, pp. 145-147.

Douvillé, H., 1926. Fossiles recueillis par Hayden dans le Kashmir en 1906 et les Pamirs en 1914. Leur description. Records of the Geological Survey of India, Calcutta 58, 349-357.

Douvillé, H., 1935. Les rudistes et leur évolution. Bulletin de la Société géologique de France 5, 319-358.

Fourcade, E., Chauve, P., Chabrier, G., 1982. Stratigraphie et tectonique de l'ile d'Tbiza témoin du prolongement de la nappe subbetique aux Baléares (Espagne). Eclogae Geologicae Helvetiae 75 (2), 415-436.

Fenerci-Masse, M., Masse, J.-P., Arias, C., Vilas, L., 2006. Archaeoradiolites a new genus from the late Aptian of the Mediterranean region and the origin of the rudist family Radiolitidae. Palaeontology 49, 769-794.

Gallo-Maresca, M., 1993. Le Radiolitidae primitive delle regioni mediterranee e del sud-ovest Asiatico. Unpublished thesis, Università di Bari, 147 pp.

Gallo-Maresca, M., Masse, J.P., 1993. Morphostructural shell organisation of primitive radiolitids and its taxonomic implications. Third Intemational Conference on rudists, Universid. Nac. Auton. Mexico, Abstracts, 25.
Gourrat, C., Masse, J.P., Skelton, P.W., 2003. Hypelasma salevensis (Favre, 1913) from the Upper Kimmeridgian of the French Jura, and the origin of the rudist family Requieniidae. Geologia Croatica 56 (2), 139-148.

Gray, J.E., 1848. On the arrangement of the Brachiopoda. Annals and Magazine of Natural History 2, 435-440.

Hill, R.T., 1893. The Paleontology of the Cretaceous formations of Texas. The invertebrate fossils of the Caprina limestones beds. Proceedings of the Biological Society of Washington 8, 97-108.

Hubmann, B., Piller, W.E., Riegl, B., 2002. Functional morphology of coral shape and passive hydrodynamic self-righting in recent Manicina areolata. Senckenbergiana Lethaea 82 (1), 125-130.

Jablonski, D., 1996. Body size and macroevolution. In: Jablonski, D., Erwin, D., Lipps, J.H. (Eds.), Evolutionary palaeobiology. University of Chicago Press, pp. 258-289.

Lamarck, J.B., 1801. Système des animaux sans vertèbres ou tableau général des classes, des ordres et des genres de ces animaux. $436 \mathrm{pp}$.

Lamarck, J.B., 1815-22. Histoire naturelle des animaux sans vertèbres. $568 \mathrm{pp}$.

de Lapeirouse, P., 1781. Description de plusieurs nouvelles espèces d'Orthocératites et d'Ostracites. Wolfgang Walther, Erlangen. $48 \mathrm{pp}$.

Masse, J.P., 1989. Relations entre modifications biologiques et phénomenes géologiques sur les plates-formes carbonatées du domaine peri-mediterraneen au passage Bédoulien-Gargasien. Géobios Mémoir 11, 279-294.

Masse, J.P., 1996. Lower Cretaceous rudist biostratigraphy of southern France. A reference for Mesogean correlations. Revista Mexicana de Ciencias Geológicas 12, 236-256.

Masse, J.P., Philip, J., 1972. Observations sur la croissance et l'ontogenese du test des Radiolitidae (Rudistes). Conséquences phylogénétiques et paléoécologiques. Comptes Rendus d l'Academie des Sciences, Paris 274, serie D, 3202-3205.

Masse, J.P., Gallo-Maresca, M., 1997. Late Aptian Radiolitidae (rudist bivalves) from the Mediterranean and southwest Asiatic regions: taxonomic, biostratigraphic and palaeobiogeographic aspects. Palaeogeography, Palaeoclimatology, Palaeoecology 128, 101-110.

Masse, J.P., Arias, C., Vilas, L., 1992. Stratigraphy and biozonation of a reference Aptian-Albian p.p. Tethyan carbonate platform succession: the Sierra del Carche series (Oriental Prebetic zone, Murcia, Spain). In: Kollman, H.A., Zapfe, H. (Eds.), New Aspects on Tethyan Cretaceous Fossil assemblages. Osterreichische Akademie Der Wissenschaften. Schriftenreihe Der Erdwissenschaftlichen Kommissio, Band 9. SpingerVerlag, pp. 201-221.

Masse, J.P., Arias, C., Vilas, L., 1998a. Lower Cretaceous rudist faunas of southeast Spain: an overview. In: Masse, J.P., Skelton, P.W. (Eds.), Quatrième Congrès International sur les Rudistes. Géobios, Memoir special 22, 193-210.

Masse, J.P., Gallo-Maresca, M., Luperto-Sinni, E., 1998b. Albian rudist faunas from southem Italy: taxonomic, biostratigraphic and palaeobiogeographic aspects. Géobios 31, 47-59.

McNamara, K.J., 1986. A guide nomenclature of heterochrony. Journal of Paleontology 60 (1), 4-13.

Milovanovic, B., 1935. Contribution à la structure de la couche externe des rudistes. Bulletin du Service Géologique, Royal de Yougoslavie 4 (1), 85-127.

Moret, L., 1936. Durania delphinensis, nouvelle espece de rudiste du Vraconien de la Fauge près Grenoble, et revision du genre Durania Douvillé. Trav. Lab. géol. Fac. Grenoble 178, 157-180.

N'da Loukou, V., 1984. Urgonien des Pyrenées occidentales. Synthese paléoécologique, micropaléontologique et paléogéographique. Unpublished Doctorat thesis, Université Pau, 317 pp.

Newell, N.D., 1965. Classification of the Bivalvia. American Museum Novitates 2006, 1-25.

d'Orbigny, A., 1842. Quelques considerations géologiques sur les rudistes. Bulletin de la Société géologique de France 13, 148-163.

Palmer, R.H., 1928. The rudists of southern Mexico. Occasional Papers of the California Academy of Sciences 14, 1-137.

Parona, C.F., 1909. Radiolites liratus (Conr.) e Apricardia notlingi (Blanck.) nel Cretaceo superiore delle Siria. At. Acad. Scien. Torino 44, 491-495. 
Parona, C.F., 1921. Fauna nel Neocretacio della Tripolitana. Molluschi, part ILamellibranchi (Rudiste). Memorie Descrittive della Carta Geologica d'Italia 8, 321 .

Pejovic, D., 1974. New Eoradiolites from Cenomanian of Serbia. Zav. Geol. Geof. Istraz. Vesn., A 31-31, 181-191.

Polsak, A., Azema, J., 1969. Durania preablayaci, nouvelle espece de Rudistes de l'Albien des cordilléres bétiques orientales (Province d'Alicante, Espagne). Quelques remarques sur le genre Durania. Bulletin de la Société géologique de France 7 (11), 638-644.

Regidor-Higuera, I., Garcia-Garmilla, F., Elorza, J., 2002. Geochemical composition of rudist shells (Bivalvia) as an indicator of diagenetic alteration vs. primitive composition (Upper Cretaceous, Northern Burgos, Spain). Sixth international Congress on Rudists, Rovinj, Croatia, Abstract and excursion guidebook, 61-63.

Rey, J., Bilotte, M., Peybernes, B., 1977. Analyse biostratigraphique et paléontologique de l'Albien marin d'Estremadura (Portugal). Géobios 10 (3), 369-393.

Sanchez, V., 1981. Hippuritidae y Radiolitidae (Bivalvia). Catalogo de especies. Publicaciones de Geologia, Universidad Autonoma de Barcelona 15, 228 pp.

Skelton, P.W., Masse, J.P., 1998. Revision of the Lower Cretaceous rudist genera Pachytraga Paquier and Retha Cox (Bivalvia: Hippuritacea) and the origins of the Caprinidae. In: Masse, J.P., Skelton, P.W. (Eds.), Quatrième Congrès Intemational sur les Rudistes. Géobios, Mémoir Spécial 22, 331-370.

Skelton, P.W., 1994. Radiations and extinctions in the history of life: what turns the "wheel of fortune"? European Palaeontological Association Newsletter - Europal 6, 15-21.

Skelton, P.W., Masse, J.P., 2000. Synoptic guide to Lower Cretaceous rudist Bivalves of Arabia. Middle East Models of Jurassic/Cretaceous Carbonate systems. Society of Economic Paleontologists and Mineralogists Special Publication 69, 89-99.
Skelton, P.W., Smith, A.B., 2000. A preliminary phylogeny for rudist bivalves: shifting clades from grades. In: Harper, E.M., Taylor, J.D., Crame, J.A. (Eds.), The Evolutionary Biology of the Bivalvia. Geological Society, Special Publication, 177, pp. 97-127.

Sliskovic, T., 1982. New Radiolitidae (Hippuritacea) from the Cretaceous deposits of Bosnia and Herzegovina. Poseb. Otis. Glasn. Zemal. Muze. 21, $1-19$.

Steuber, T., 1999. Cretaceous rudists of Boeotia, central Greece. Special Papers in Palaeontology 61, 1-229.

Steuber, T., 2003. Strontium isotope stratigraphy of Cretaceous hippuritid rudist bivalves: rates of morphological changes and heterochronic evolution. Palaeogeography, Palaeoclimatology, Palaeoecology 200, 221-243.

Steuber, T., Yilmaz, C., Löser, H., 1998. Growth rates of early Campanian rudists in siliciclastic-calcareous setting (Pontide Mts., north central Turkey). In: Masse, J.P., Skelton, P.W. (Eds.), Quatrième Congrès International sur les Rudistes. Géobios, Mémoir Spécial 22, 331-370.

Steuber, T., Bachmann, M., 2002. Upper Aptian-Albian rudist bivalves from northern Sinai, Egypt. Palaeontology 45 (4), 725-749.

Strum, D.H., Perkins, B.F. 1975. Architecture of Radiolitid Rudist (Mollusca). Shell-wall structure and its phylogenetic implications. $33 \mathrm{rd}$. Ann. Procee Elect. Micr. Soc. America, 686-687.

Tavani, G., 1948. Fauna malacologica cretacea della Somalia e dell Ogaden. Palaeontographica Italiana 43 (n. s. 13), 83-153.

Torre, D., 1965. Rudiste presenoniane delle Murge barese. Palaeontographica Italiana 59 (n. sp. 29), 63-83.

Toucas, A., 1907. Etudes sur la classification et l'évolution des Radiolitidae. Bulletin de la Société géologique de France Mémoir 36 (14), 1-46.

de Verneuil, E., Collomb, E., Triger, A., 1860. Note sur une partie du pays basque espagnol accompagnée d'une carte. Bulletin de la Société géologique de France 2 (17), 333-372. 